\title{
18. GEOCHEMISTRY OF BASALTS FROM THE NAURU BASIN, DEEP SEA DRILLING PROJECT LEGS 61 AND 89: IMPLICATIONS FOR THE ORIGIN OF OCEANIC FLOOD BASALTS 1
}

\author{
A. D. Saunders, Department of Geology, University of Leicester ${ }^{2}$
}

\begin{abstract}
At Site 462 in the Nauru Basin, western Pacific Ocean, 56 lithologic units have been recovered from an extensive flood basalt province. Fossil evidence suggests that the lavas were emplaced during the interval $100-115 \mathrm{Ma}$, some 30 m.y. after formation of the underlying Jurassic ocean crust. The lithologic units can be broadly divided into three chemical units, the lowermost two of which are chemically monotonous, suggesting rapid eruption of basalt from a compositionally homogeneous magma chamber. All the basalts are hypersthene- (hy-) rich tholeites, with approximately chondritic $\mathrm{La} / \mathrm{Sm}, \mathrm{La} / \mathrm{Yb}, \mathrm{Zr} / \mathrm{Nb}, \mathrm{La} / \mathrm{Ta}$, and $\mathrm{Th} / \mathrm{Hf}$ ratios. Chemically they resemble, in part, "transitional" mid-ocean ridge basalts (MORB) from areas such as the Reykjanes Ridge, although $\mathrm{Rb}, \mathrm{Ba}$, and $\mathrm{K}$ contents are very low and similar to those of "normal" MORB. Their ${ }^{87} \mathrm{Sr} /{ }^{86} \mathrm{Sr}$ ratios are higher than in N-type MORB (Fujii et al., 1981). The chemistry of the Nauru basalts differs from that of continental flood basalts, which tend to be strongly enriched in large-ion lithophile (LIL) elements, although the extent to which the differences result from sialic contamination or source variability is not clear.
\end{abstract}

\section{INTRODUCTION}

The Nauru Basin lies in the western Pacific Ocean, to the west of the Marshall Islands (Fig. 1). The basin was originally drilled during Leg 61 of the Deep Sea Drilling Project, a primary objective of which was to investigate the structure of fast-spreading $(4.7 \mathrm{~cm} / \mathrm{yr}$. half-rate) $\mathrm{Ju}-$ rassic Pacific crust. Detailed magnetic surveys had previously indicated that the oceanic basement beneath the Nauru Basin formed at a spreading center some 148 m.y. ago, in the late Jurassic. Coring at Hole 462A during Leg 61, however, recovered a sequence of massive basaltic sills and flows interlayered with sediments having a postulated Barremian, Lower Cretaceous fauna in the lowermost units (Larson, Schlanger, et al., 1981). Failure to reach Jurassic ocean crust was offset, however, by the realization that extensive areas of the Nauru Basin floor are underlain by a thick carapace of basaltic sheet flows and sills, which represent voluminous Early Cretaceous intraplate activity (see reviews by Schlanger and Premoli Silva, 1981, and Larson, Schlanger, et al., 1978). In several respects, the Nauru Basin province is analogous to continental flood basalt provinces, most notably in the vast volumes of magma produced. In this account, therefore, the term "oceanic flood basalt" will be used.

Hole $462 \mathrm{~A}$ was revisited during Leg 89 and deepened by a further $140.5 \mathrm{~m}$, giving a total sub-bottom penetration of $1204 \mathrm{~m}$. Much of this deeper section comprises massive basaltic sheet flows compositionally identical to the immediately overlying units drilled during Leg 61 . Poorly recovered sediment interlayers indicate deposition during the latest Jurassic to Aptian, but reanalysis of Leg 61 sediment from Core $462 \mathrm{~A}-80$ suggests that it is

\footnotetext{
${ }^{1}$ Moberly, R., Schlanger, S. O., et al., Init. Repts. DSDP, 89: Washington (U.S. Govt. Printing Office).

2 (Address):Department of Geology, University of Leicester, Leicester, LE1 7RH, U.K.
}

Aptian rather than Barremian (Site 462 chapter, this volume). Thus, Leg 89 drilling also failed to reach the predicted Jurassic basement.

The purpose of this chapter is to present major- and trace-element data for a suite of basalts recovered during both Leg 61 and Leg 89. High-precision trace-element data are used to characterize the composition of the source of the Nauru Basin flood basalts and to compare it with the sources of MORB and continental flood provinces. The Nauru Basin basalts may be of particular importance in understanding the origin and sourceevolution of continental flood basalts because, having been erupted through ocean crust, they will not have undergone sialic contamination (cf. Carlson et al., 1981; DePaolo and Wasserburg, 1979).

\section{LITHOLOGY AND AGE OF BASALTIC VOLCANISM}

The Leg 61 shipboard party divided the igneous section of the upper part of the Hole $462 \mathrm{~A}$ section (Cores $462 \mathrm{~A}-15$ to $462 \mathrm{~A}-92$ ) into 44 lithologic units, on the basis of textural variations, chilled margins, sediment interlayers, and downhole logging. A brief summary is presented in Figure 2, and the reader is referred to Initial Reports Vol. 61 (Larson, Schlanger, et al., 1981) for details of these units. The Leg 61 lithologies were divided into two broad categories: an uppermost section (Units $462 \mathrm{~A}-1$ to $462 \mathrm{~A}-32$ ) of predominantly intrusive, sill-like bodies, and a lower section of massive sheet flows. No pillow lavas were reported.

A further 12 lithologic units were recognized in the core recovered during Leg 89 , and all of them have been interpreted as massive basaltic sheet flows; only in one (Unit 462A-51) were the structures suggestive of pillow flows seen. The thicknesses of Units $462 \mathrm{~A}-45$ to $462 \mathrm{~A}$ 56 vary from less than $1 \mathrm{~m}$ to [rarely] over $30 \mathrm{~m}$ (Fig. 2), 


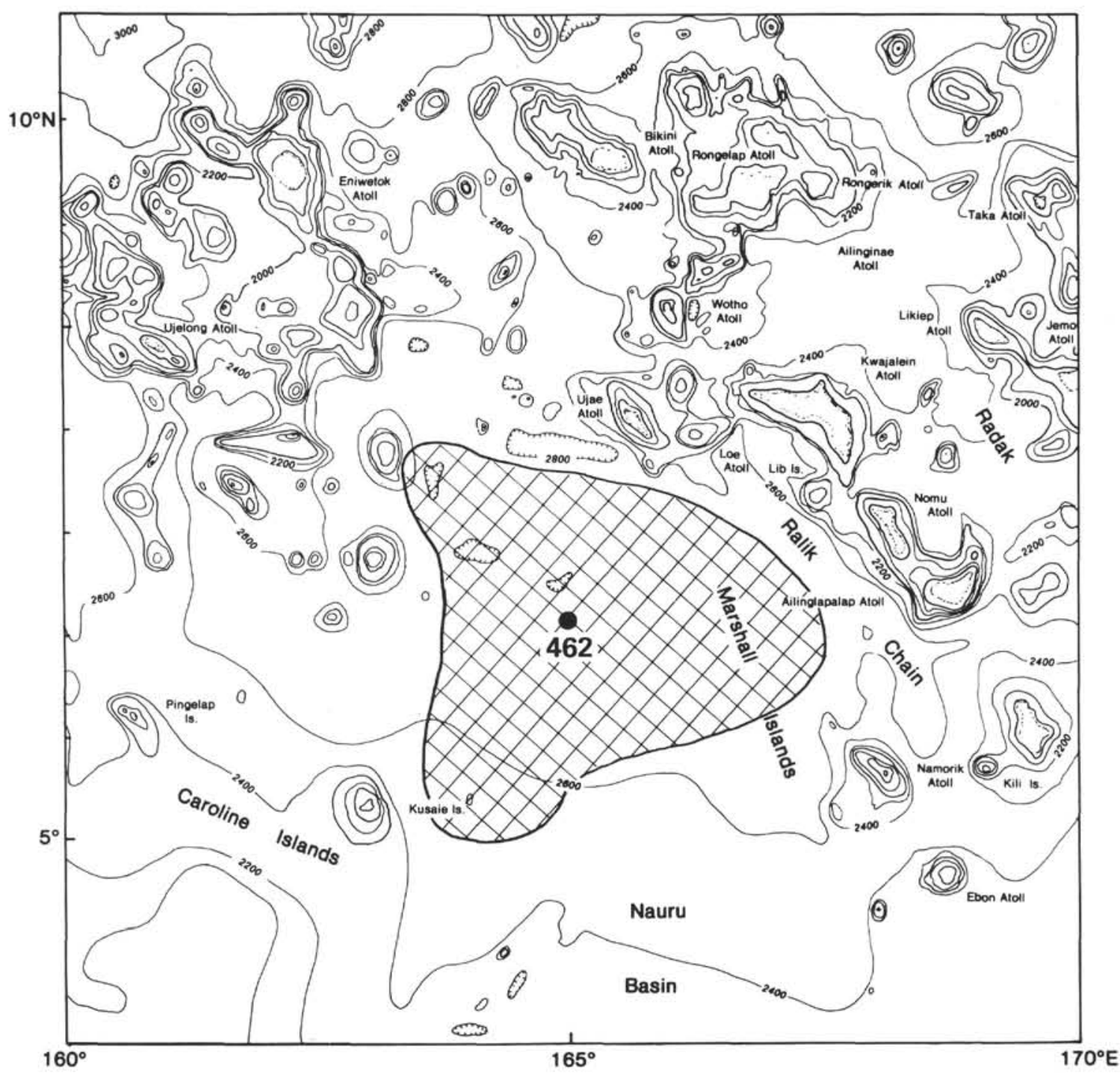

Figure 1. Bathymetric map showing the regional setting of Site 462 and the postulated extent of the Nauru Basin basalt province. Depths in meters. From Larson, Schlanger, et al. (1981) with modifications after Larson and Schlanger (1981) and Winterer (1976).

a range similar to the range of thicknesses observed during Leg $61(<1$ to rarely $50 \mathrm{~m})$ and not very different from the thicknesses of massive flows drilled during Leg 65 (20-m-thick flows were not uncommon) (Lewis, Robinson, et al., 1983). For further details of the lithology of Units $462 \mathrm{~A}-45$ to $462 \mathrm{~A}-56$, the reader is referred to the Site 462 chapter (this volume).

Evaluating the timing and duration of the Nauru Basin activity is difficult because of the paucity of fossil evidence and the earlier interpretations of the mode of emplacement of the igneous units. In particular, earlier suggestions that the upper part of Hole $462 \mathrm{~A}$ comprises sills, rather than flows, should be reassessed in the light of recent studies of sill emplacement in the Gulf of California (Curray, Moore, et al., 1982; Einsele et al., 1980). Recognition of intrusive units in drill cores is difficult because they may be confused with massive sheet flows. The evidence cited in the Site 462 chapter (Larson, Schlanger, et al., 1981)-namely, (1) fine-grained or glassy margins with sub-horizontal attitudes; (2) orderly, in- ward-coarsening grain-size variations, with (3) diabasictextured interiors-is not unequivocal proof that a unit represents a sill. Many igneous units drilled during Leg 65 at $23^{\circ} \mathrm{N}$ on the East Pacific Rise (EPR) exhibit these features, but the absence of hydrothermal alteration that can be related to intrusion of magma into the sediment column precludes them from being sills (see Lewis, Robinson, et al., 1983). Positive evidence which can be used to support an intrusive origin includes the following:

1. Thermal baking and discoloration of sediment immediately adjacent to the upper contact of the body.

2. Development of hydrothermal minerals in the sediment-contact aureole above the unit (such effects were detected several tens of meters above sills recovered in the Gulf of California: Curray, Moore, et al., 1982).

3 . Increase in bulk density of sediments as the upper contact of the body is approached, resulting from thermal expulsion of pore waters (Einsele et al., 1980).

4. Obvious intrusive contacts where a sill has intruded a preexsisting igneous unit. 


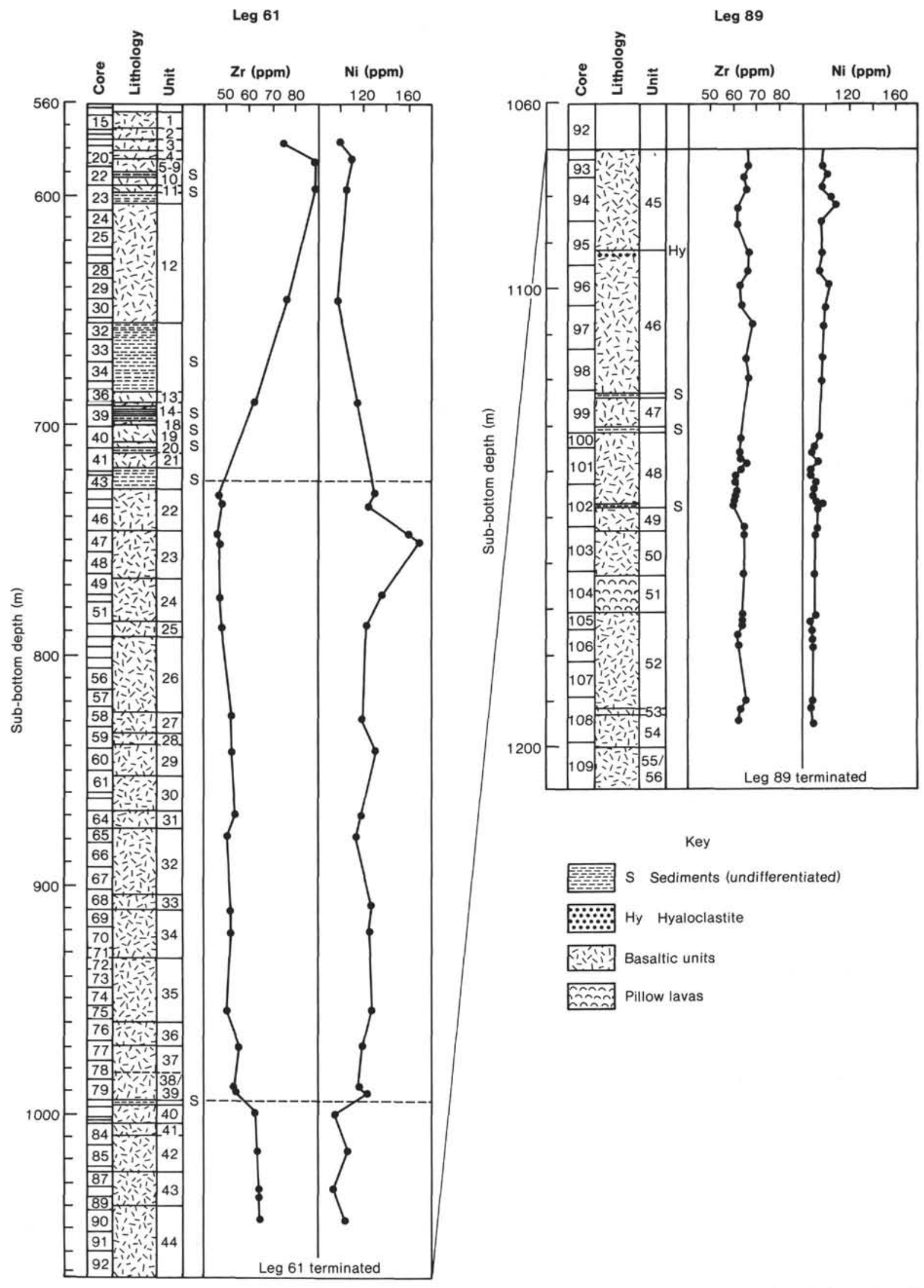

Figure 2. Downhole lithological and geochemical logs for the Hole 462A succession. Note the expanded vertical scale for the Leg 89 stratigraphy. Data sources: Leg 61, Larson, Schlanger, et al., (1981); Leg 89, Site 462 site chapter (this volume); $\mathrm{Zr}$ and $\mathrm{Ni}$ analyses, Table 3. 
5. Thermal maturation of organic compounds in sediments above igneous units (Simoneit and Philip, 1982).

It is not clear that such evidence is present in the Hole 462A lithologies. In particular, the recovery of metamorphosed sediments (Moberly and Jenkins, 1981) is equivocal evidence of intrusive activity, unless it can be disproven that heating resulted from subsequent extrusive activity; given the relative thinness of the sediment interlayers found in Hole 462A, such distinction is unlikely to be possible. The evidence from lipid maturation analysis is also equivocal (Thompson et al., 1981), an unexpected result in view of the massive nature of the igneous units (cf. Simoneit and Philip, 1982).

With the presently available evidence, therefore, the suggestion that the upper part of Hole 462A comprises sill-like bodies must be treated with caution.

The date at which the igneous activity began at Site 462 is uncertain, because the oldest basalt units have not been drilled. The oldest dated sediments, from Section 462A-99-1, contain the radiolarian Holocryplocaspa hindei, which has a range from latest Jurassic to earliest Aptian (Site 462 chapter, this volume). Core $462 \mathrm{~A}-80$ contains sediments deposited in the early Aptian (about $112 \mathrm{Ma}$ ), and also contains reworked pre-early Hauterivian radiolarian fauna; Core $462 \mathrm{~A}-46$ contains Aptian fauna (108-115 Ma) and reworked Berriasian fauna. Core 462A-40 contains late Aptian fauna (about $108 \mathrm{Ma}$ ) (Larson, Schlanger, et al., 1981). Above the igneous complex, Core 462A-13 contains late Albian to Cenomanian fauna 462A-32. The radiometric and faunal data therefore suggest that the igneous complex at Hole 462A was emplaced within the interval $115-100 \mathrm{Ma}$, although there are no precise age data available for Units $462 \mathrm{~A}-40$ to $462 \mathrm{~A}-56$. It is interesting that the duration of activity is of an order of magnitude similar to that of the Columbia River flood basalt province ( $\sim 11 \mathrm{~m}$.y.; Swanson et al., 1979).

\section{PETROGRAPHY}

Details of the petrography and mineralogy of the basalts from Hole $462 \mathrm{~A}$ can be obtained from the relevant site chapters; only a brief summary will be given here.

All the holocrystalline basalts contain plagioclase (Plag), clinopyroxene (Cpx), Fe-Ti oxides, and secondary minerals. Many units contain smectite pseudomorphs after olivine (Ol), but some flows contain olivine in fresh glass. In the lower parts of the section, olivine is entirely replaced by smectite and iddingsite, and there is evidence that the primary content of olivine decreases downhole. Textures vary widely, from glassy quenched margins through variolitic to ophitic flow centers, although even the holocrystalline basalts have patchy textures with frequent hyalopilitic domains. The flows recovered during Leg 89 do not exhibit any ophitic textures.

Most of the basalts are aphyric or contain less than $10 \%$ phenocrysts. Plagioclase or spinel and olivine appear to be the main liquidus phases of the Leg 61 basalts, followed rapidly by pyroxene. In the Leg 89 basalts, the three common phenocryst assemblages are $\mathrm{O} 1$ $+\mathrm{Cpx}$, Plag $+\mathrm{Cpx}$, and $\mathrm{O} 1+\mathrm{Cpx}+\mathrm{Plag}$, although aphyric basalts are again common. Concentration of mi- crophenocrysts in the base of Unit 462A-45 may reflect crystal settling, but otherwise cumulate textures are not seen in the Hole 462A succession. In most samples we appear to be dealing with liquid compositions.

All the studied basalts exhibit some degree of secondary alteration, but in general the effects are slight. In the lowermost flows cored on Legs 89 and 61, veins within the basalt contain variable amounts of zeolite, smectites, pyrite, calcite, minor quartz, and apophyllite (Windom and Book, 1981), indicative of metamorphism as lower zeolite facies. Away from the veins, glass and olivine are commonly altered to smectite. That the alteration is slight compared with most drilled MORB is indicated by chemical data. Thus, $\mathrm{H}_{2} \mathrm{O}^{+}$in Leg 89 basalt is less than 1.0 wt. $\% ; \delta^{18} \mathrm{O}$ values from Leg 61 samples generally indicate less than 5\% alteration (Batiza et al., 1981); and the very low abundances of $\mathrm{K}, \mathrm{Rb}$, and $\mathrm{Ba}$ in most of the basalts from Hole 462A (Batiza et al., 1981, and Geochemistry section of this chapter) imply little interaction between basalt and sediment pore water or seawater.

The low degree of alteration within the Nauru Basin basalts is unexpected, but could stem from several factors: (1) the basaltic activity postdates the basement age by as much as $38 \mathrm{~m}$.y. by which time the intense hydrothermal activity associated with ridge-crest volcanism will have ceased; (2) rapid effusion of successive flows will cap and seal underlying flows from seawater; (3) the low volumetric ratio of sediment to basalt within much of the succession will restrict the chemical effects of basalt-porewater exchange.

\section{METHODS}

\section{Sample Preparation}

Whole-rock samples weighing 20 to $30 \mathrm{~g}$ were cut from the freshest portions of the core, boiled in distilled water to remove salt water and cutting paste, and dried at $110^{\circ} \mathrm{C}$ for 20 minutes. The rock fragments were then pulverized in a mechanical jaw crusher preparatory to grinding in an agate-lined Tema swingmill. The use of an agate rather than a tungsten carbide mill eliminates $\mathrm{Ta}$ and $\mathrm{Nb}$ contamination (cf. Joron et al., 1980).

Nine-gram aliquots of powder were mixed with $1.5 \mathrm{~g}$ of Bakelite resin and formed into 40 -mm briquettes for X-ray fluorescence (XRF) analysis of minor and trace elements. Representative powders were dried overnight at $120^{\circ} \mathrm{C}$, fused with Johnson-Matthey lithium tetraborate-lithium carbonate Spectroflux 104 at $1000^{\circ} \mathrm{C}$, and formed into glass discs for XRF analysis of major elements.

Aliquot (0.4-g) specimens of representative samples were encapsulated in plastic for irradiation at the University of London Reactor Centre, Ascot, prior to neutron activation analysis.

To ensure compatibility of results, identical preparation techniques have been used for basalts from Legs $34,54,55,61,89$, and 91 .

\section{Analytical Techniques}

Sixty-two samples formed into powder briquettes were analyzed for minor and trace elements, using a Philips PW1400 wavelength-dispersive XRF machine at Bedford College, University of London. Analytical techniques were similar to those outlined by Tarney et al. (1979), except that $\mathrm{TiO}_{2}, \mathrm{P}_{2} \mathrm{O}_{5}, \mathrm{~K}_{2} \mathrm{O}, \mathrm{Zr}, \mathrm{Nb}, \mathrm{Y}, \mathrm{Sr}$, and $\mathrm{Rb}$ were determined on a Ag-anode $\mathrm{X}$-ray tube and the elements $\mathrm{Ni}, \mathrm{Cr}, \mathrm{Ba}$, and $\mathrm{V}$ on a Wanode X-ray tube. Line overlaps of $\mathrm{Sr}$ on $\mathrm{Zr} K_{\alpha}, \mathrm{Rb}$ on $\mathrm{Y}$, Th on $\mathrm{Nb}$, $\mathrm{Nb}$ on $\mathrm{Y}$, and $\mathrm{Ce}$ on $\mathrm{Ba}$ were corrected. Mass absorption has been corrected using the $\mathrm{Ag}$-tube line, W-tube line, or bulk-rock absorption coefficients $(\mathrm{Cr}, \mathrm{V}, \mathrm{Ba})$, where appropriate.

Ten representative samples were analyzed as replicate glass discs for major elements, using the Ag-anode $\mathrm{X}$-ray tube. The fusion tech- 
nique ensured sample homogenization, eliminated mineralogical effects, and minimized mass-absorption problems. Corrections for mass absorption were nonetheless made. The low fusion temperature of Spectroflux 104 minimizes $\mathrm{Na}$ volatilization.

Calibration lines were continually checked using International Standard Reference Samples, and long-term machine drift was corrected using internal standards. Accuracy of results can be assessed only by comparison with International Standards, none of which compares with the depleted chemistry of MORB or Nauru Basin basalts. The analysis of a national reference standard, the ocean-floor basalt BOB1 , may be used, however, to cross-check the present data with previous analyses of IPOD basalts (Table 1). Analytical precision, based on replicate analyses, is generally high; for the present samples, it is as follows: $\mathrm{Zr}, \pm 2 \mathrm{ppm} ; \mathrm{Nb}, \pm 1 \mathrm{ppm} ; \mathrm{Y}, \pm 2 \mathrm{ppm} ; \mathrm{Sr}, \pm 1 \mathrm{ppm} ; \mathrm{Ni}, \pm 3$ ppm; Cr, \pm 2 ppm; V, \pm 2 ppm; Ba, \pm 3 ppm. For the major elements, precision is generally better than $\pm 1 \%$.

The elements La, Ce, Nd, Sm, Eu, Gd, Tb, Tm, Yb, Lu, Th, Hf, and Ta were determined on seven samples, using instrumental neutron activation techniques described by Saunders (1983). The 97.4-KeV 153 Gd and $84.3-\mathrm{KeV}^{170} \mathrm{Tm}$ peaks were often found to be difficult to measure accurately.

Throughout the analytical program, every effort was made to ensure compatibility between the Nauru Basin results and the analyses of basalts from other Pacific provinces, in particular those recovered on Leg 34 (Nazca Plate), Leg 54 (EPR and Galapagos), Leg 55 (Hawaiian and Emperor seamounts), Leg 65 (Gulf of California), and Leg 91 (Western Pacific Jurassic crust). Many of these results are as yet unpublished; they form part of a larger project investigating the evolution of the Pacific Basin. However, the analyses form a precise data base from which detailed comparisons between the Nauru Basin basalts and other basalt provinces can reliably be drawn.

\section{GEOCHEMISTRY}

Major-element analyses of representative basalts from Hole 462A, together with CIPW norms, are given in Ta- ble 2. All the basalts have a high content of normative hypersthene, and straddle the diopside-hypersthene join on the basalt tetrahedron (Fig. 3). Quartz-normative tholeiites are rare in the oceanic environment (Chayes, 1972), but the extension of the Hole $462 \mathrm{~A}$ data into the field of silica oversaturation is only very slight; most of the samples fall within the field of EPR $23^{\circ} \mathrm{N}$ basalts recovered during Leg 65. All the analyzed basalts have $\mathrm{MgO}$ (and $\mathrm{Ni}$ ) abundances too low for them to represent realistic primary mantle melts (e.g., Green, 1971; Kay et al., 1970; O'Hara, 1973; Dick, 1977), indicating that the melts underwent olivine fractionation before eruption.

Downhole variations in chemistry are best studied with minor- and trace-element data (Table 3 and Fig. 2). Zr, for example, an element considered to be incompatible in most basaltic systems, is a sensitive indicator of fractionation, is precisely analyzed by XRF, and is not susceptible to low-grade alteration (Pearce and Cann, 1973; Tarney et al., 1979, 1980). It has been plotted on Figure 2 to illustrate downhole chemical variations at Site 462 . The total range in $\mathrm{Zr}$ abundances is not great (46-90 ppm), but is sufficient to distinguish three main chemical units: Unit I, comprising lithologic Units 462A-15 to $462 \mathrm{~A}-21$, with variably high $\mathrm{Zr}$ contents $(62-90 \mathrm{ppm})$; Unit II, comprising Units $462 \mathrm{~A}-22$ to $462 \mathrm{~A}-39$, with low $\mathrm{Zr}$ contents (46-55 ppm); and Unit III, comprising Units $462 \mathrm{~A}-40$ to $462 \mathrm{~A}-56$, with intermediate $\mathrm{Zr}$ contents (61$68 \mathrm{ppm}$ ). Each of these three chemical units is separated from the next by a sediment horizon, implying a pause in the main eruptive cycle. Apart from chemical Unit I, which has variable $\mathrm{Zr}$ levels, the distribution of $\mathrm{Zr}$ (and

Table 1. Major-element analyses of Nauru Basin basalts from Hole 462A.

\begin{tabular}{|c|c|c|c|c|c|c|c|c|c|c|}
\hline $\begin{array}{c}\text { Sample (interval in } \mathrm{cm} \text { ) } \\
\text { Unit }\end{array}$ & $\begin{array}{c}21-1,87-90 \\
7\end{array}$ & $\begin{array}{c}23-4,74-76 \\
11\end{array}$ & $\begin{array}{c}44-1,54-57 \\
22\end{array}$ & $\begin{array}{c}47-3,30-32 \\
23\end{array}$ & $\begin{array}{c}69-1,55-57 \\
34\end{array}$ & $\begin{array}{c}70-2,79-82 \\
34\end{array}$ & $\begin{array}{c}94-7,0-3 \\
45\end{array}$ & $\begin{array}{c}97-3,13-17 \\
46\end{array}$ & $\begin{array}{c}101-5,19-25 \\
48\end{array}$ & $\begin{array}{l}108-2,0-3 \\
52\end{array}$ \\
\hline $\mathrm{SiO}_{2}$ & 49.8 & 49.0 & 49.7 & 49.6 & 49.6 & 49.7 & 50.6 & 49.7 & 50.9 & 49.8 \\
\hline $\mathrm{TiO}_{2}$ & 1.87 & 1.99 & 0.94 & 0.95 & 1.08 & 1.07 & 1.21 & 1.35 & 1.22 & 1.33 \\
\hline $\mathrm{Al}_{2} \mathrm{O}_{3}$ & 14.0 & 14.6 & 14.8 & 14.9 & 14.2 & 14.4 & 14.0 & 14.4 & 13.9 & 14.0 \\
\hline $\mathrm{Fe}_{2} \mathrm{O}_{3}$ & 1.57 & 1.64 & 1.40 & 1.42 & 1.42 & 1.47 & 1.57 & 1.62 & 1.60 & 1.67 \\
\hline $\mathrm{FeO}$ & 10.48 & 10.91 & 9.31 & 9.44 & 9.46 & 9.79 & 10.47 & 10.81 & 10.65 & 11.16 \\
\hline $\mathrm{MnO}$ & 0.25 & 0.21 & 0.24 & 0.22 & 0.20 & 0.20 & 0.21 & 0.21 & 0.21 & 0.26 \\
\hline $\mathrm{MgO}$ & 6.59 & 6.83 & 8.36 & 7.56 & 8.02 & 8.05 & 7.50 & 7.05 & 7.11 & 7.14 \\
\hline $\mathrm{CaO}$ & 10.80 & 10.87 & 12.60 & 12.74 & 12.44 & 12.52 & 11.42 & 11.61 & 11.52 & 11.58 \\
\hline $\mathrm{Na}_{2} \mathrm{O}$ & 2.48 & 2.62 & 2.06 & 2.00 & 2.01 & 2.05 & 2.13 & 2.46 & 2.24 & 2.43 \\
\hline $\mathrm{K}_{2} \mathrm{O}$ & 0.09 & 0.10 & 0.07 & 0.05 & 0.06 & 0.05 & 0.07 & 0.07 & 0.06 & 0.10 \\
\hline $\mathrm{P}_{2} \mathrm{O}_{5}$ & 0.14 & 0.17 & 0.08 & 0.07 & 0.10 & 0.08 & 0.09 & 0.10 & 0.09 & 0.09 \\
\hline Total & 98.04 & 98.75 & 99.59 & 99.00 & 98.59 & 99.35 & 99.28 & 99.33 & 99.59 & 99.53 \\
\hline Mg no. ${ }^{a}$ & 52.9 & 52.7 & 61.5 & 58.8 & 60.2 & 59.4 & 56.1 & 53.8 & 54.3 & 53.3 \\
\hline \multicolumn{11}{|l|}{ CIPW norms } \\
\hline $\mathrm{Qz}$ & 1.1 & 0.0 & 0.0 & 0.0 & 0.0 & 0.0 & 1.1 & 0.0 & 1.3 & 0.0 \\
\hline Or & 0.5 & 0.6 & 0.4 & 0.3 & 0.4 & 0.3 & 0.4 & 0.4 & 0.4 & 0.6 \\
\hline $\mathrm{Ab}$ & 21.4 & 22.4 & 17.5 & 17.1 & 17.2 & 17.5 & 18.2 & 21.0 & 19.0 & 20.7 \\
\hline An & 27.3 & 28.3 & 31.0 & 32.0 & 29.9 & 30.1 & 28.6 & 28.2 & 27.9 & 27.1 \\
\hline $\mathrm{Ne}$ & 0.0 & 0.0 & 0.0 & 0.0 & 0.0 & 0.0 & 0.0 & 0.0 & 0.0 & 0.0 \\
\hline Di & 21.9 & 21.1 & 25.5 & 25.8 & 26.3 & 26.1 & 23.0 & 24.1 & 23.8 & 24.8 \\
\hline $\mathrm{Hy}$ & 21.5 & 16.8 & 16.7 & 18.9 & 20.4 & 18.3 & 23.9 & 17.4 & 22.7 & 17.6 \\
\hline OI & 0.0 & 4.6 & 4.8 & 1.9 & 1.4 & 3.3 & 0.0 & 3.8 & 0.0 & 4.0 \\
\hline Mt & 2.4 & 2.4 & 2.1 & 2.1 & 2.2 & 2.1 & 2.3 & 2.4 & 2.3 & 2.4 \\
\hline Ilm & 3.6 & 3.4 & 1.8 & 1.8 & 2.1 & 2.0 & 2.3 & 2.6 & 2.3 & 2.5 \\
\hline $\mathrm{Hm}$ & 0.0 & 0.0 & 0.0 & 0.0 & 0.0 & 0.0 & 0.0 & 0.0 & 0.0 & 0.0 \\
\hline $\mathrm{Ap}_{\mathrm{b}}$ & 0.3 & 0.3 & 0.2 & 0.2 & 0.2 & 0.2 & 0.2 & 0.2 & 0.2 & 0.2 \\
\hline D.I. ${ }^{b}$ & 23.1 & 23.0 & 17.9 & 17.4 & 17.6 & 17.8 & 19.7 & 21.4 & 20.7 & 21.3 \\
\hline
\end{tabular}

Note: $\mathrm{Fe}_{2} \mathrm{O}_{3}$ and $\mathrm{FeO}, \mathrm{Mg}$ numbers, and $\mathrm{CIPW}$ norms calculated using $\mathrm{Fe}_{2} \mathrm{O}_{3} / \mathrm{FeO}$ ratio of 0.15 . Major-element oxides and $\mathrm{CIPW}$ norms. in wt. \%.

${ }^{\mathrm{a}} \mathrm{Mg}$ number $=100 \mathrm{Mg} /(\mathrm{Mg}+\mathrm{Fe})$.

b.I. = Qz + Or + Ab. 
Table 2. Analyses of standard reference samples, Bob-1.

\begin{tabular}{ccc}
\hline & Bob-1 ${ }^{\mathrm{a}}$ & Bob-1 $^{\mathrm{b}}$ \\
\hline Major elements (wt.\%) & & \\
& & \\
$\mathrm{SiO}_{2}$ & 50.5 & 50.1 \\
$\mathrm{TiO}_{2}$ & 1.33 & 1.33 \\
$\mathrm{Al}_{2} \mathrm{O}_{3}$ & 16.5 & 16.3 \\
$\mathrm{tFe}_{2} \mathrm{O}_{3}$ & 9.12 & 8.2 \\
$\mathrm{MnO}$ & 0.15 & 0.15 \\
$\mathrm{MgO}$ & 7.6 & 7.4 \\
$\mathrm{CaO}$ & 11.77 & 10.8 \\
$\mathrm{Na}$ & 3.0 & 3.04 \\
$\mathrm{~K}_{2} \mathrm{O}$ & 0.38 & 0.37 \\
$\mathrm{P}_{2} \mathrm{O}_{5}$ & 0.13 & 0.16
\end{tabular}

Trace elements (ppm)

$\begin{array}{lcr}\mathrm{Ni} & 107 & 125 \\ \mathrm{Cr} & 236 & 258 \\ \mathrm{Rb} & 4.7 & 6 \\ \mathrm{Sr} & 199 & 188 \\ \mathrm{Y} & 26 & 27 \\ \mathrm{Zr} & 102 & 97 \\ \mathrm{Nb} & 5 & 6 \\ \mathrm{Ba} & 57 & 55\end{array}$

a Saunders (1983).

This study.

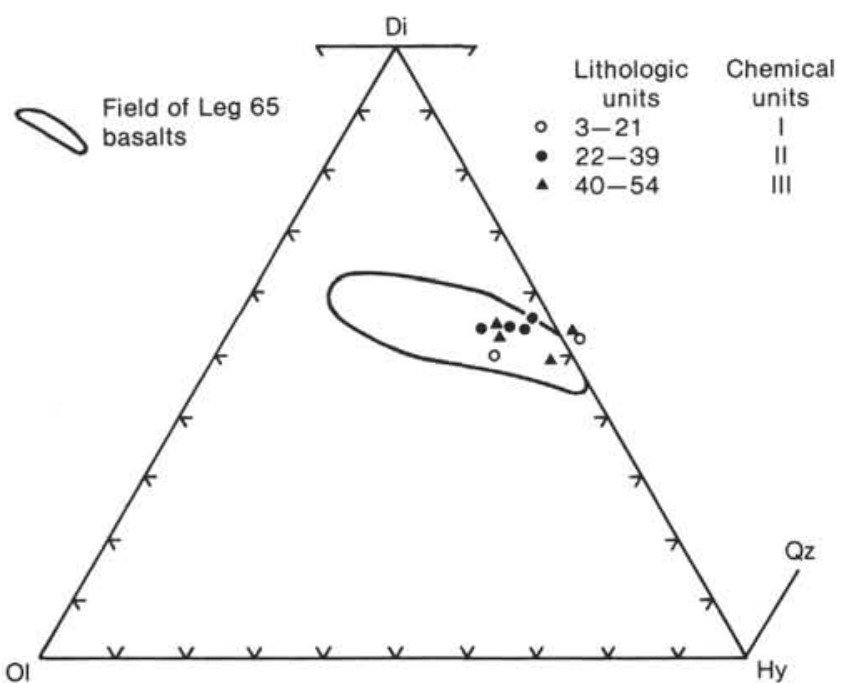

Figure 3. Hole $462 \mathrm{~A}$ basalts plotted on the normative nepheline (Ne)olivine (Ol)-diopside (Di)-hypersthene (Hy)-quartz (Qz) tetrahedron. Normative mineralogy calculated using $\mathrm{Fe}_{2} \mathrm{O}_{3} / \mathrm{FeO}$ ratio of 0.15. Leg 65 data from Saunders (1983).

other incompatible elements) is monotonous, remarkably constant over thick eruptive sequences.

Judging from the generally higher abundances of incompatible elements (e.g., Zr, Ti, P, Y) in chemical Unit I, this unit evidently comprises more fractionated basalts. This is indicated also by the generally lower $\mathrm{MgO}$ and $\mathrm{Ni}$ contents of this unit, and was reported by the Leg 61 petrologists (Shcheka, 1981; Tokuyama and Batiza, 1981; Batiza, 1981).

Variations within individual lithologic units are reported here only for the Leg 89 basalts, where the sample density is sufficiently high. Units $462 \mathrm{~A}-45$ and $462 \mathrm{~A}-48$ show slight enhancement in $\mathrm{Zr}$ content in their upper parts, although the range is very small. It is not clear whether this variation is due to flow differentiation or to chemical heterogeneities in the parental magma.

The abundances of the large-ion lithophile (LIL) elements $\mathrm{K}, \mathrm{Rb}$, and $\mathrm{Ba}$ are generally very low (Table 3 ), and are similar to the abundances reported in fresh, chemically depleted MORB from the Nazca Plate (Thompson et al., 1976), Mid-Atlantic Ridge (MAR) $22^{\circ} \mathrm{N}$ (Bougault, Treuil, et al., 1979; Bougault, Cambon, et al., 1979), and the Gulf of California (Saunders, 1983). The low abundances of $\mathrm{K}, \mathrm{Rb}$, and $\mathrm{Ba}$ imply that the analyzed basalts have undergone little chemical modification during low-temperature secondary alteration. It is well documented that low-T exchange with seawater enriches these elements (e.g., Hart et al., 1974) and, although it is demonstrable that high-grade hydrothermal activity can leach $\mathrm{K}, \mathrm{Rb}$, and $\mathrm{Ba}$ from the ocean crust (Saunders et al., 1979; Stern and Elthon, 1979), none of the Nauru Basin basalts has attained a sufficiently high grade for this to have been an important process. If the basalts have indeed undergone minimal exchange with seawater or sediment pore water, the ${ }^{87} \mathrm{Sr} /{ }^{86} \mathrm{Sr}$ ratios reported by Fujii et al. (1981) probably represent magmatic values. These ratios $(0.7036-0.7039)$ are significantly higher than in most MORB (see discussion following and Castillo et al., this volume).

Seven basalts from Hole 462A were analyzed for the rare earth elements (REE), Hf, Ta, and Th (Table 3 ). The chondrite-normalized patterns are flat (Fig. 4), with $\mathrm{La}_{n} / \mathrm{Yb}_{n}$ ratios ranging from 0.8 to 1.1 . The basalts from chemical Unit I are slightly light-REE-enriched; those from Units II and III are light-REE-depleted (Fig. 5). These differences are slight, but they nonetheless indicate that the basalts of Unit I cannot be derived from a parental magma with composition of Unit III basalts, although they could by derived from Unit II-type basalts if sufficient pyroxene (and hence $\mathrm{Yb}$ ) is extracted from the melt. Alternatively, all three chemical types could be derived from a common, more primitive parental magma with a $\mathrm{La}_{n} / \mathrm{Yb}_{n}$ ratio of just less than 1 . Note that the two samples from chemical Unit I have identical $\mathrm{La}_{n} / \mathrm{Yb}_{n}$ ratios, implying control during high-level fractionation of olivine and/or plagioclase, with insignificant pyroxene removal. None of the presently determined REE patterns exhibits a Eu anomaly; this is consistent with petrographic observations that plagioclase removal or addition was insignificant, although Batiza (1981) reported small negative Eu anomalies in some basalts from Units I and II.

The Nauru Basin basalts have low absolute abundances of $\mathrm{Ta}, \mathrm{Nb}, \mathrm{Th}$, and $\mathrm{Hf}$, although $\mathrm{Zr} / \mathrm{Nb}$ and $\mathrm{Zr} / \mathrm{Ta}$ ratios are lower than in most MORB (Fig. 6, and see discussion following). The $\mathrm{Zr} / \mathrm{Nb}(\sim 15), \mathrm{Zr} / \mathrm{Ta}(\sim 270)$, $\mathrm{La} / \mathrm{Ta}(15-16)$, and $\mathrm{Th} / \mathrm{Hf}(\sim 0.20)$ ratios are essentially chondritic. $\mathrm{Ti} / \mathrm{Zr}$ ratios ( $\sim 120$ : Fig. 7$)$ are higher than chondrite values ( 110: Sun and Nesbitt, 1977).

\section{DISCUSSION}

Volumetrically, the Nauru Basin basalts probably equal or even exceed the size of several of the better-known 
continental flood basalt provinces. Seismic reflection data indicate that some $400,000 \mathrm{~km}^{2}$ of the Nauru Basin is floored by intraplate basalts which, if we assume an average thickness of $0.5 \mathrm{~km}$, gives a volume of some $200,000 \mathrm{~km}^{3}$ (Larson, Schlanger, et al., 1981; Tokuyama and Batiza, 1981). The Miocene Columbia River Province, by comparison, has a volume of some $200,000 \mathrm{~km}^{3}$ (Swanson and Wright, 1978). Therefore, the Leg 61 and Leg 89 cores have provided a sample, admittedly very small, of a basalt province of major significance. In this section I will briefly review the characteristics of this basalt activity, and compare the chemistry of the basalts with that of basalts from other, better-documented provinces.

The absence of volcanic centers which can be directly associated with the Nauru Basin basalts suggests that the lavas were erupted from fissures, in a style similar to eruption of the Columbia River lavas. At the risk of stretching this analogy too far, one may note that the chemistry of the Nauru basalts remains remarkably constant over thick eruptive sequences. Thus, chemical Units 462-II and 462A-III encompass 18 and 14 lithologic units, respectively, and yet, the incompatible-trace-element contents of the two chemical units remain virtually the same throughout (Fig. 2). Available data from the Columbia River Province indicate a similar distribution; there, the activity can be divided into distinct episodes, the most volumetric being the Grande Ronde Formation (Swanson, et al., 1979; Swanson and Wright, 1978), but still the basalts appear to show little chemical variation within each eruptive episode (e.g., Carlson et al., 1981).

This is in marked contrast to the rapid chemical cyclicity which characterizes many sections of the ocean crust. Cores from the Nazca Plate (Thompson et al., 1976; A. D. Saunders, unpublished), Gulf of California (Saunders, 1983), and western Pacific (Legs 86, 88, 89: Saunders, unpublished) all record considerable downhole variations in chemistry with, for example, low-Fe $/ \mathrm{Mg}$ basalt being erupted before (or after) high- $\mathrm{Fe} / \mathrm{Mg}$ basalts. In this environment, it is not uncommon for $\mathrm{Zr}$ to show a twofold change between adjacent lithologic units. Such chemical cyclicity in ocean-ridge basalts is thought to arise because of eruption of successive magma batches from rapidly evolving, discrete subridge magma chambers. The absence of cyclicity in the Nauru Basin basalts precludes a rapidly evolving magma chamber(s), although the constant composition within chemical Units 462A-II and 462A-III implies either (1) a large reservoir of homogeneous magma and/or (2) relatively short eruption times preventing the evolution of the magma within a chamber. The latter concurs with the paucity of sediment interlayers within chemical Units $462 \mathrm{~A}-\mathrm{II}$ and $462 \mathrm{~A}-\mathrm{III}$ and the constant magnetic polarity of these two units.

Variations in the absolute abundances of incompatible elements can be used to monitor the evolution of magmas, but they are of lesser value when comparing the petrogenesis of basalts from different provinces. Here, it is more usual to consider ratios between trace-element and isotope pairs, thus minimizing the effects of highlevel fractionation. Ideally, we wish to compare the compositions of the (hypothetical) primary magmas, or even mantle sources, supplying the different basalt provinces.
Ratios of the highly incompatible (or hygromagmatophile, HYG) elements $\mathrm{La}, \mathrm{Ce}, \mathrm{Ta}, \mathrm{Nb}, \mathrm{Th}, \mathrm{Ba}, \mathrm{K}$, and $\mathrm{Rb}$, together with $\mathrm{Sr}-, \mathrm{Nd}-$, and $\mathrm{Pb}$-isotope data, have proved to be of particular value in evaluating the chemical evolution of MORB. Most MORB erupted along topographically "normal" ridge segments (hence the term Ntype MORB) have very low abundances of these elements, distinctively low $\mathrm{La}_{\mathrm{n}} / \mathrm{Yb}_{\mathrm{n}}(<0.7)$ and $\mathrm{Th} / \mathrm{Hf}(<0.1)$ ratios, and high $\mathrm{Zr} / \mathrm{Nb}(\sim 30), \mathrm{La} / \mathrm{Ta}(\sim 18)$, and $\mathrm{K} / \mathrm{Rb}$ ( $\sim 900)$ ratios (see Table 4 for details and references). Gast (1968) and Schilling (1975) demonstrated that the light-REE depletion of N-type MORB is a characteristic of their mantle source, a conclusion supported by subsequent detailed studies of incompatible-element pairs and isotope ratios (O'Nions et al., 1977, 1979; Sun et al., 1979; Tarney et al., 1980). N-type MORB occur along much of the EPR and MAR, and appear to comprise much of the Pacific and Atlantic basement, suggesting that their source is of worldwide extent.

In several respects-notably their tholeiitic nature, low absolute abundances of $\mathrm{K}, \mathrm{Rb}$, and $\mathrm{Ba}$, and their high $\mathrm{K} / \mathrm{Rb}$ ratios-the Nauru basalts closely resemble $\mathrm{N}$-type MORB. There are, however, some important differences. The lower $\mathrm{Zr} / \mathrm{Nb}$ and $\mathrm{Zr} / \mathrm{Ta}$ ratios, higher $\mathrm{La} / \mathrm{Yb}$ and $\mathrm{La} / \mathrm{Sm}$ ratios, and, most important, much higher ${ }^{87} \mathrm{Sr}$ / ${ }^{86} \mathrm{Sr}$ ratios (0.7038 instead of 0.7027: Fujii et al., 1981), are atypical of N-type MORB. These chemical differences are illustrated by Figure 7, a multi-element diagram in which the data have been normalized against an $\mathrm{N}$-type MORB. The sample selected for the plot (462A$23-4,74-76 \mathrm{~cm}$ ) has a $\mathrm{Zr}$ content of $90 \mathrm{ppm}$, similar to the normalization value of $88 \mathrm{ppm}$, which allows us to compare lavas which have experienced similar degrees of high-level fractionation. The most significant deviation from unity is seen in the elements $\mathrm{Th}, \mathrm{La}, \mathrm{Ce}, \mathrm{Nb}, \mathrm{Ta}$, and $\mathrm{Ti}$, all of which are higher than in N-type MORB. The abundance of $\mathrm{Ba}$ is also higher, but note the earlier comments regarding the potential mobility of this element.

These chemical differences between the Nauru basalts and N-type MORB could (in theory) be explained by differing degrees of partial melting of a common source. For example, the ratio $\mathrm{Ta} / \mathrm{Zr}$ (Fig. 6) could by susceptible to pyroxene or garnet fractionation, since removal of these phases reduces the $\mathrm{Zr}$ content of the melt (although it would also significantly reduce the heavy REE, and such a reduction is not observed). Derivation of the Nauru basalts and N-type MORB from compositionally similar parental melts and even similar mantle sources can, however, be discounted on two grounds. First, production of tholeiitic melts-generally assumed to represent 10 to $15 \%$ melting of spinel lherzolite (e.g., Green, 1971) - is unlikely to give rise to such distinctive and different trace-element patterns. Bear in mind that $\mathrm{N}$-type MORB have, partly by definition, remarkably constant incompatible-trace-element ratios (e.g., Fig. 6), despite the fact that they erupted at ridges with different spreading rates, over at least 150 m.y. of Earth history. For the Nauru basalts, simply reducing the degree of partial melting to increase the $\mathrm{Ta}$ and $\mathrm{Nb}$ abundances would of course enhance the concentrations of other incompatible elements, unless we invoke residual minor phases during 
Table 3. Minor- and trace-element analyses of Nauru Basin Site 462 basalt.

\begin{tabular}{|c|c|c|c|c|c|c|c|c|c|c|c|}
\hline $\begin{array}{l}\text { Sample (interval in } \mathrm{cm} \text { ) } \\
\text { [unit] }\end{array}$ & $\begin{array}{c}19-1,23-25 \\
{[3]}\end{array}$ & $\begin{array}{c}21-1,87-90 \\
{[7]}\end{array}$ & $\begin{array}{l}23-4,74-76 \\
\text { [111] }\end{array}$ & $\begin{array}{l}30-2,15-21 \\
{[12]}\end{array}$ & $\begin{array}{c}38-1,96-99 \\
{[14]}\end{array}$ & $\begin{array}{c}44-1,54-57 \\
{[22]}\end{array}$ & $\begin{array}{l}45-3,0-3 \\
{[22]}\end{array}$ & $\begin{array}{c}47-2,12-14 \\
{[23]}\end{array}$ & $\begin{array}{c}47-3,30-32 \\
{[23]}\end{array}$ & $\underset{[24]}{50-1,13-15}$ & $\begin{array}{c}52-3,19-21 \\
{[25]}\end{array}$ \\
\hline $\mathrm{TiO}_{2}$ & 1.32 & 1.87 & 1.99 & 1.67 & 1.23 & 0.94 & 0.94 & 0.90 & 0.95 & 0.93 & 1.00 \\
\hline $\mathrm{K}_{2} \mathrm{O}$ & 0.10 & 0.09 & 0.10 & 0.50 & 0.08 & 0.07 & 0.05 & 0.05 & 0.05 & 0.06 & 0.06 \\
\hline $\mathrm{P}_{2}^{2} \mathrm{O}_{5}$ & 0.13 & 0.14 & 0.17 & 0.15 & 0.13 & 0.08 & 0.10 & 0.09 & 0.07 & 0.10 & 0.10 \\
\hline $\mathrm{Ni}$ & 96 & 110 & 103 & 95 & 113 & 128 & 123 & 158 & 168 & 133 & 121 \\
\hline $\mathrm{Cr}$ & 150 & 196 & 188 & 205 & 155 & 401 & 360 & 435 & 484 & 373 & 350 \\
\hline v & 293 & 387 & - & 353 & 288 & 285 & 274 & 270 & - & 270 & 271 \\
\hline $\mathrm{Rb}$ & 2 & $<1$ & 1 & 5 & 1 & 1 & 1 & $<1$ & 1 & 1 & $<1$ \\
\hline Sr & 123 & 122 & 125 & 108 & 108 & 82 & 84 & 81 & 83 & 83 & 89 \\
\hline $\mathrm{Y}$ & 27 & 32 & 40 & 29 & 25 & 20 & 21 & 20 & 23 & 21 & 20 \\
\hline $\mathrm{Zr}_{\mathrm{r}}$ & 73 & 90 & 90 & 76 & 62 & 46 & 47 & 46 & 47 & 47 & 48 \\
\hline Hf & 2.14 & - & 2.60 & - & - & - & - & - & 1.52 & - & - \\
\hline $\mathrm{Nb}$ & 5 & 6 & 7 & 4 & 4 & 3 & 4 & 3 & 4 & 3 & 3 \\
\hline $\mathrm{Ta}$ & 0.27 & - & 0.34 & - & - & - & - & - & 0.20 & - & - \\
\hline $\mathrm{Ba}$ & 12 & 28 & 25 & 27 & 10 & 5 & $<1$ & 7 & 7 & 12 & 3 \\
\hline La & 4.30 & - & 5.45 & - & - & - & - & - & 3.11 & - & - \\
\hline $\mathrm{Ce}$ & 11.55 & - & 13.90 & - & - & - & - & - & 8.85 & - & - \\
\hline Nd & 8.68 & - & 10.95 & - & - & - & - & - & 6.16 & - & - \\
\hline $\mathrm{Sm}$ & 3.05 & - & 3.49 & - & - & - & - & - & 2.19 & - & - \\
\hline Eu & 1.10 & - & 1.28 & - & - & - & - & - & 0.86 & - & - \\
\hline Gd & - & $\overline{-}$ & $\begin{array}{l}4.85 \\
\end{array}$ & - & $=$ & $=$ & $=$ & $\overline{-}$ & 3.21 & - & - \\
\hline $\mathrm{Tb}$ & 0.68 & - & 0.87 & - & - & - & - & - & 0.57 & - & - \\
\hline $\mathrm{Tm}$ & 0.42 & - & 0.59 & - & - & - & - & - & - & - & - \\
\hline $\mathrm{Yb}$ & 2.67 & - & 3.40 & - & - & - & - & - & 2.64 & - & - \\
\hline Lu & - & - & 0.59 & - & - & - & - & - & 0.43 & - & - \\
\hline Th & 0.41 & - & 0.53 & - & - & - & - & - & 0.26 & - & - \\
\hline \multicolumn{12}{|l|}{ Element ratios } \\
\hline $\mathrm{Rb} / \mathrm{Sr}$ & 0.016 & - & 0.008 & 0.046 & 0.009 & 0.012 & 0.012 & - & 0.012 & 0.012 & - \\
\hline $\mathrm{Ba} / \mathrm{Sr}$ & 0.098 & 0.230 & 0.200 & 0.250 & 0.093 & 0.061 & - & 0.086 & 0.084 & 0.145 & 0.034 \\
\hline $\mathrm{Nb} / \mathrm{Ba}$ & 0.417 & 0.214 & 0.280 & 0.148 & 0.400 & 0.600 & - & 0.429 & 0.571 & 0.250 & 1.000 \\
\hline $\mathrm{Ba} / \mathrm{La}$ & 2.8 & - & 4.6 & - & - & - & - & - & 2.3 & - & - \\
\hline $\mathrm{La} / \mathrm{Nb}$ & 0.86 & - & 0.78 & - & - & - & - & - & 0.78 & - & - \\
\hline $\mathrm{La} / \mathrm{Ta}$ & 15.9 & - & 16.0 & - & - & - & - & - & 15.5 & - & - \\
\hline $\mathrm{Th} / \mathrm{Ta}$ & 1.52 & - & 1.56 & $\underline{-}$ & $\overline{-}$ & - & - & - & 1.30 & - & - \\
\hline $\mathrm{Th} / \mathrm{Hf}$ & 0.19 & - & 0.20 & - & - & - & - & - & 0.17 & - & - \\
\hline $\mathrm{Ti} / \mathrm{Zr}$ & 108.4 & 124.6 & 132.6 & 131.7 & 118.9 & 122.5 & 119.9 & 117.3 & 121.2 & 118.6 & 124.9 \\
\hline $\mathrm{Zr} / \mathrm{Hf}$ & 34.1 & - & 34.6 & - & - & - & - & - & 30.9 & - & - \\
\hline $\mathrm{Nb} / \mathrm{Ta}$ & 18.5 & - & 20.6 & - & - & - & - & - & 20.0 & - & - \\
\hline $\mathrm{Zr} / \mathrm{Nb}$ & 14.6 & 15.0 & 12.9 & 19.0 & 15.5 & 15.3 & 11.8 & 15.3 & 11.8 & 15.7 & 16.0 \\
\hline$(\mathrm{La} / \mathrm{Ta}) \mathrm{n}^{\mathrm{a}}$ & 1.07 & - & 1.08 & - & - & - & - & - & 1.04 & - & - \\
\hline$\left(\mathrm{Th} / \mathrm{HN} \mathrm{n}^{\mathrm{a}}\right.$ & 0.91 & $=$ & 0.97 & $\overline{-}$ & $\overline{-}$ & - & - & - & 0.81 & - & - \\
\hline$(\mathrm{Ti} / \mathrm{Zr}) \mathrm{n}^{\mathrm{a}}$ & 1.60 & 1.84 & 1.96 & 1.94 & 1.75 & 1.81 & 1.77 & 1.73 & 1.79 & 1.75 & 1.84 \\
\hline$(\mathrm{La} / \mathrm{Y}) \mathrm{n}^{\mathrm{a}}$ & 0.9 & - & 0.8 & - & - & - & - & - & 0.8 & - & - \\
\hline$(\mathrm{La} / \mathrm{Yb}) \mathrm{n}^{\mathrm{a}}$ & 1.1 & - & 1.1 & - & - & - & - & - & 0.8 & - & - \\
\hline$(\mathrm{La} / \mathrm{Sm})^{\mathrm{a}}$ & 0.9 & - & 1.0 & - & - & - & - & - & 0.9 & - & - \\
\hline
\end{tabular}

Note: $\mathrm{TiO}_{2}, \mathrm{~K}_{2} \mathrm{O}$, and $\mathrm{P}_{2} \mathrm{O}_{5}$ in wt.\%. All other elements in ppm. Dash indicates not determined.

basalt generation. However, the stability of such phases, particularly during the generation of tholeiitic melts, is probably too low to be of significance.

Second, the ${ }^{87} \mathrm{Sr} /{ }^{86} \mathrm{Sr}$ ratios are too high for the Nauru basalts to have been derived directly from an N-type MORB source (Fujii et al., 1981). It is possible that the high ${ }^{87} \mathrm{Sr} /{ }^{86} \mathrm{Sr}$ ratio indicates secondary alteration, or contamination of the magma with sediment before emplacement. The ${ }^{87} \mathrm{Sr} /{ }^{86} \mathrm{Sr}$ ratios are remarkably constant throughout Hole 462A, however, and leaching in acid did not significantly reduce the ${ }^{87} \mathrm{Sr} /{ }^{86} \mathrm{Sr}$ ratios (Fujii et al., 1981). In addition, the low Ba contents of many of the basalts preclude significant assimilation of pelagic sediments, which often have very high contents of $\mathrm{Ba}$ (e.g., Hole et al., 1984).

The data suggest, therefore, that the Nauru basalts were derived from a parental magma (and probably a mantle source) enriched in ${ }^{87} \mathrm{Sr}, \mathrm{Ta}, \mathrm{Nb}, \mathrm{Th}, \mathrm{La}$, and $\mathrm{Ce}$, relative to the Cenozoic $\mathrm{N}$-type MORB source. Of course, late Jurassic/Early Cretaceous Pacific crust may have been of a different composition than the present-day crust, implying that the N-type MORB reservoir has evolved with time. Although there are few comprehensive analyses of upper Jurassic ocean crust-and none from the
Nauru Basin - the available data do not support such a suggestion. During drilling in the southwestern Pacific, coring on DSDP Leg 91 recovered basalts of apparently late Jurassic age (Natland et al., 1983). Although previously unpublished, data for these basalts have been included in most of the geochemical plots, and an analysis is included in Table 4. It can be seen that, apart from those elements susceptible to alteration ( $\mathrm{K}$ and $\mathrm{Rb}$ in particular), these tholeiites are indistinguishable from $\mathrm{N}$ type MORB from the EPR and Nazca Plate. Therefore, the basalts erupted during formation of the Jurassic ancestral Pacific crust drilled during Leg 91 were essentially similar to those of the present day.

$\mathrm{N}$-type MORB are not the only basalts found in the ocean basins. The MAR, for example, is presently erupting chemically enriched basalts along several ridge segments-most notably at Iceland, $45^{\circ} \mathrm{N}$, and the Azores Plateau intersection-which have been related to mantle hot-spots or plumes (Schilling, 1975) or, less specifically, to regions of chemically enriched mantle (Tarney et al., 1980; Bougault et al., 1980). Termed enriched or E-type MORB, these basalts characteristically exhibit strong lightREE-, Nb-, Ta-, and Th-enrichment, and, in terms of trace-element contents, more closely resemble the (usu- 
Table 3 (continued).

\begin{tabular}{|c|c|c|c|c|c|c|c|c|c|c|c|}
\hline $\begin{array}{c}58-3,37-39 \\
{[27]}\end{array}$ & $\begin{array}{c}60-1,102-105 \\
{[29]}\end{array}$ & $\begin{array}{c}64-1,17-20 \\
{[31]}\end{array}$ & $\begin{array}{c}65-2,94-96 \\
{[32]}\end{array}$ & $\begin{array}{c}69-1,55-57 \\
{[34]}\end{array}$ & $\begin{array}{c}70-2,79-82 \\
{[34]}\end{array}$ & $\begin{array}{c}75-1,85-87 \\
{[35]}\end{array}$ & $\begin{array}{c}77-3,8-10 \\
{[37]}\end{array}$ & $\begin{array}{c}79-4,105-107 \\
{[38]}\end{array}$ & $\begin{array}{c}79-5,79-82 \\
{[38 / 39]}\end{array}$ & $\begin{array}{c}81-2,82-84 \\
{[40]}\end{array}$ & $\begin{array}{c}85-2,33-35 \\
{[42]}\end{array}$ \\
\hline 1.09 & 1.08 & 1.07 & 1.07 & 1.08 & 1.07 & 1.00 & 1.11 & 1.08 & 1.09 & 1.29 & 1.22 \\
\hline 0.05 & 0.08 & 0.06 & 0.06 & 0.06 & 0.05 & 0.08 & 0.08 & 0.06 & 0.06 & 0.08 & 0.07 \\
\hline 0.11 & 0.10 & 0.11 & 0.11 & 0.10 & 0.10 & 0.12 & 0.11 & 0.11 & 0.11 & 0.12 & 0.12 \\
\hline 118 & 131 & 116 & 113 & 125 & 123 & 125 & 119 & 116 & 122 & 94 & 105 \\
\hline 343 & 351 & 320 & 319 & 342 & 330 & 319 & 261 & 290 & 305 & 170 & 219 \\
\hline 295 & 295 & 281 & 287 & 295 & - & 264 & 286 & 283 & 280 & 325 & 323 \\
\hline 1 & 2 & 2 & 1 & 1 & 1 & 1 & $<1$ & $<1$ & $<1$ & $<1$ & $<1$ \\
\hline 91 & 93 & 91 & 89 & 88 & 89 & 94 & 95 & 95 & 93 & 85 & 97 \\
\hline 22 & 22 & 21 & 23 & 21 & 23 & 22 & 22 & 23 & 24 & 27 & 25 \\
\hline 52 & 52 & 53 & 50 & 52 & 52 & 50 & 55 & 53 & 53 & 63 & 64 \\
\hline- & - & - & - & 1.55 & - & - & - & - & - & - & - \\
\hline 4 & 5 & 4 & 3 & 2 & 5 & 4 & 3 & 5 & 3 & 4 & 4 \\
\hline- & - & - & - & 0.21 & - & - & - & - & - & - & - \\
\hline 14 & $<1$ & 7 & 13 & 2 & 10 & 15 & 7 & 9 & 10 & 15 & 15 \\
\hline- & - & - & - & 2.71 & - & - & - & - & - & - & - \\
\hline- & - & - & - & 8.11 & - & - & - & - & - & - & - \\
\hline- & - & - & - & 6.47 & - & - & - & - & - & - & - \\
\hline- & - & - & - & 2.30 & - & - & - & - & - & - & - \\
\hline- & - & - & - & 0.91 & - & - & - & - & - & - & - \\
\hline- & - & - & - & 3.31 & - & - & - & - & - & - & - \\
\hline- & - & - & - & 0.56 & - & - & - & - & - & - & - \\
\hline- & - & - & - & - & - & - & - & - & - & - & - \\
\hline- & - & - & - & 2.37 & - & - & - & - & - & - & - \\
\hline- & - & - & - & 0.38 & - & - & - & - & - & - & - \\
\hline- & - & - & - & 0.35 & - & - & - & - & - & - & - \\
\hline 0.011 & 0.022 & 0.022 & 0.011 & 0.011 & 0.011 & 0.011 & - & - & - & - & - \\
\hline 0.154 & - & 0.077 & 0.146 & 0.023 & 0.112 & 0.160 & 0.074 & 0.095 & 0.108 & 0.176 & 0.155 \\
\hline 0.286 & - & 0.571 & 0.231 & 1.000 & 0.500 & 0.267 & 0.429 & 0.556 & 0.300 & 0.267 & 0.267 \\
\hline- & - & - & - & 0.7 & - & - & - & - & - & - & - \\
\hline- & - & - & - & 1.36 & - & - & - & - & - & - & - \\
\hline- & - & - & - & 12.9 & - & - & - & - & - & - & - \\
\hline- & - & - & - & 1.67 & - & - & - & - & - & - & - \\
\hline- & - & - & - & 0.23 & - & - & - & - & - & - & - \\
\hline 125.7 & 124.5 & 121.0 & 128.3 & 124.5 & 123.3 & 119.9 & 121.0 & 122.2 & 123.3 & 122.7 & 114.3 \\
\hline- & - & - & - & 33.5 & - & - & - & - & - & - & - \\
\hline- & - & - & - & 9.5 & - & - & - & - & - & - & - \\
\hline 13.0 & 10.4 & 13.3 & 16.7 & 26.0 & 10.4 & 12.5 & 18.3 & 10.6 & 17.7 & 15.8 & 16.0 \\
\hline- & - & - & - & 0.87 & - & - & - & - & - & - & - \\
\hline- & - & - & - & 1.07 & - & - & - & - & - & - & - \\
\hline 1.85 & 1.84 & 1.79 & 1.89 & 1.84 & 1.82 & 1.77 & 1.78 & 1.80 & 1.82 & 1.81 & 1.69 \\
\hline- & - & - & - & 0.8 & - & - & - & - & - & - & - \\
\hline- & - & - & - & 0.8 & - & - & - & - & - & - & - \\
\hline- & - & - & - & 0.7 & - & - & - & - & - & - & - \\
\hline
\end{tabular}

ally silica-undersaturated) basalts found on ocean islands (e.g., Wood et al., 1981). They contain far higher abundances of the highly incompatible elements than do the Nauru Basin basalts, despite often having higher $\mathrm{Mg}$ / $(\mathrm{Mg}+\mathrm{Fe})$ ratios.

Ridge segments occupying intermediate locations between "elevated" and "normal" ridge segments-for example, Reykjanes Ridge and FAMOUS-erupt basalts transitional in chemistry between these two main end-members (e.g., Wood, Tarney, et al., 1979). Loosely termed transitional or T-type MORB, they exhibit very diverse chemistries; it is therefore not surprising that a T-type MORB can be found which is broadly similar to the Nauru Basin basalt. Such a basalt, from the Reykjanes Ridge (Table 4), is plotted on Figure 8 . Note the broadly similar forms of the plots, in particular the high $\mathrm{Nb}$ and $\mathrm{Ta}$ contents. The degree of light-REE enrichment is approximately the same in the Nauru basalts (Fig. 5), although the La/Ta ratios are lower ( 9) (Fig. 9).

The comparison with the Reykjanes Ridge and the Icelandic plateau is of interest because it suggests that the Nauru Basin may have tapped a geochemical source similar to that presently underlying Iceland. Clearly, the Mid-Atlantic Ridge in the vicinity of Iceland is under- lain by "fertile" mantle, inasmuch as the basalt effusion rates are significantly higher than at adjacent ridge segments. Whether this apparent fertility is caused by a deepseated mantle plume (Schilling, 1975) or a broad, regional chemical anomaly, is not clear. Nonetheless, a similar tectonic setting may be responsible for the Early Cretaceous outpourings recorded in the Nauru Basin; that is, the thickened ocean crust results from eruption in both ridge-axis and off-axis settings, and the drilling at Site 462 has penetrated only the youngest part of the sequence. This inevitably leads to the suggestion that perhaps there is no clear break between ridge-generated "Jurassic" basement and the off-axis volcanism, but rather a continuous sequence of eruptions akin to that at Iceland. This problem can be resolved only by further drilling at Site 462 or at other locations within the Nauru Basin.

Other oceanic regions where the crustal structure is anomalously thick (for example the Ontong-Java Plateau, Manihiki Plateau, Shatsky Rise, and the Caribbean flood basalt province) have been poorly sampled, but their lavas appear similar to the Nauru basalts in terms of available major- and trace-element chemistry (Batiza, 1981; Bence et al., 1975). Far more detailed sampling and geochemical data are required. however, before we 
Table 3 (continued).

\begin{tabular}{|c|c|c|c|c|c|c|c|c|c|c|}
\hline $\begin{array}{l}\text { Sample (interval in } \mathrm{cm} \text { ) } \\
\text { [unit] }\end{array}$ & $\begin{array}{l}88-2,64-67 \\
{[43]}\end{array}$ & $\underset{[43]}{89-1,91-92}$ & $\begin{array}{c}90-4,88-90 \\
{[44]}\end{array}$ & $\begin{array}{c}93-1,82-85 \\
{[45]}\end{array}$ & $\begin{array}{c}93-2,16-19 \\
{[45]}\end{array}$ & $\underset{[45]}{94-2,133-136}$ & $\begin{array}{c}94-5,137-170 \\
{[45]}\end{array}$ & $\underset{[45]}{94-7,0-3}$ & $\begin{array}{c}95-1,27-30 \\
{[45]}\end{array}$ & $\begin{array}{c}95-7,19-21 \\
{[46]}\end{array}$ \\
\hline $\mathrm{TiO}_{2}$ & 1.27 & 1.34 & 1.45 & 1.48 & 1.42 & 1.40 & 1.29 & 1.26 & 1.31 & 1.42 \\
\hline $\mathrm{K}_{2} \mathrm{O}$ & 0.08 & 0.08 & 0.06 & 0.09 & 0.08 & 0.07 & 0.07 & 0.07 & 0.07 & 0.08 \\
\hline $\mathrm{P}_{2} \mathrm{O}_{5}$ & 0.12 & 0.12 & 0.13 & 0.14 & 0.12 & 0.12 & 0.13 & 0.12 & 0.12 & 0.13 \\
\hline $\mathrm{Ni}$ & 94 & 97 & 103 & 95 & 100 & 95 & 101 & 108 & 95 & 97 \\
\hline $\mathrm{Cr}$ & 180 & 181 & 179 & 163 & 179 & 162 & 182 & 231 & 167 & 169 \\
\hline v & 324 & 382 & 357 & - & - & - & - & - & - & - \\
\hline $\mathrm{Rb}$ & 1 & 1 & $<1$ & 2 & $<1$ & $<1$ & $<1$ & $<1$ & 1 & 1 \\
\hline $\mathrm{Sr}$ & 95 & 97 & 95 & 95 & 95 & 96 & 103 & 92 & 94 & 96 \\
\hline $\mathbf{Y}$ & 27 & 26 & 28 & 28 & 28 & 27 & 27 & 26 & 26 & 28 \\
\hline $\mathrm{Zr}$ & 64 & 64 & 65 & 66 & 64 & 65 & 63 & 61 & 61 & 67 \\
\hline $\mathrm{Hf}$ & - & - & - & - & - & 2.10 & - & - & - & - \\
\hline $\mathrm{Nb}$ & 5 & 3 & 4 & 4 & 5 & 4 & 4 & 5 & 4 & 5 \\
\hline $\mathrm{Ta}$ & - & - & - & - & - & 0.25 & - & - & - & - \\
\hline $\mathrm{Ba}$ & 23 & 20 & 10 & 17 & 16 & 10 & 11 & 12 & 13 & 15 \\
\hline $\mathrm{La}$ & - & - & - & - & - & 3.90 & - & - & - & - \\
\hline $\mathrm{Ce}$ & - & - & - & - & - & 10.61 & - & - & - & - \\
\hline $\mathrm{Nd}$ & - & - & - & - & - & 8.47 & - & - & - & - \\
\hline $\mathrm{Sm}$ & - & - & - & - & - & 2.89 & - & - & - & - \\
\hline Eu & - & - & - & - & - & 1.10 & - & - & - & - \\
\hline Gd & - & - & - & - & - & - & - & - & - & - \\
\hline $\mathrm{Tb}$ & - & - & - & - & - & 0.73 & - & - & - & - \\
\hline $\mathrm{Tm}$ & - & - & - & - & - & - & - & - & - & - \\
\hline $\mathrm{Yb}$ & - & - & - & - & - & 3.15 & - & - & - & - \\
\hline $\mathrm{Lu}$ & - & - & - & - & - & 0.54 & - & - & - & - \\
\hline Th & - & - & - & - & - & 0.39 & - & - & - & - \\
\hline \multicolumn{11}{|l|}{ Element ratios } \\
\hline $\mathrm{Rb} / \mathrm{Sr}$ & 0.011 & 0.010 & - & 0.021 & - & - & - & - & 0.011 & 0.010 \\
\hline $\mathrm{Ba} / \mathrm{Sr}$ & 0.242 & 0.206 & 0.105 & 0.179 & 0.168 & 0.104 & 0.107 & 0.130 & 0.138 & 0.156 \\
\hline $\mathrm{Nb} / \mathrm{Ba}$ & 0.217 & 0.150 & 0.400 & 0.235 & 0.313 & 0.400 & 0.364 & 0.417 & 0.308 & 0.333 \\
\hline $\mathrm{Ba} / \mathrm{La}$ & - & - & - & - & - & 2.6 & - & - & - & - \\
\hline $\mathrm{La} / \mathrm{Nb}$ & - & - & - & - & - & 0.98 & - & - & - & - \\
\hline $\mathrm{La} / \mathrm{Ta}$ & - & - & - & - & - & 15.6 & - & - & - & - \\
\hline $\mathrm{Th} / \mathrm{Ta}$ & - & - & - & - & - & 1.56 & - & - & - & - \\
\hline $\mathrm{Th} / \mathrm{Hf}$ & - & - & - & - & - & 0.19 & - & - & - & - \\
\hline $\mathrm{Ti} / \mathrm{Zr}$ & 119.0 & 125.5 & 133.7 & 134.4 & 133.0 & 129.1 & 122.7 & 123.8 & 128.7 & 127.0 \\
\hline $\mathrm{Zr} / \mathrm{Hf}$ & - & - & - & - & - & 31.0 & - & - & - & - \\
\hline $\mathrm{Nb} / \mathrm{Ta}$ & - & - & - & - & - & 16.0 & - & - & - & - \\
\hline $\mathrm{Zr} / \mathrm{Nb}$ & 12.8 & 21.3 & 16.3 & 16.5 & 12.8 & 16.3 & 15.8 & 12.2 & 15.3 & 13.4 \\
\hline$(\mathrm{La} / \mathrm{Ta}) \mathrm{n}^{\mathrm{a}}$ & - & - & - & - & - & 1.05 & - & - & - & - \\
\hline$(\mathrm{Th} / \mathrm{H}) \mathrm{n}^{\mathrm{a}}$ & - & - & - & - & - & 0.88 & - & - & - & - \\
\hline$(\mathrm{Ti} / \mathrm{Zr}) \mathrm{n}^{\mathrm{a}}$ & 1.76 & 1.85 & 1.97 & 1.98 & 1.96 & 1.90 & 1.81 & 1.83 & 1.90 & 1.87 \\
\hline$(\mathrm{La} / \mathrm{Y}) \mathrm{n}^{\mathrm{a}}$ & - & - & - & - & - & 0.9 & - & - & - & - \\
\hline$(\mathrm{La} / \mathrm{Yb}) \mathrm{n}^{\mathrm{a}}$ & - & - & - & - & - & 0.8 & - & - & - & - \\
\hline$(\mathrm{La} / \mathrm{Sm}) \mathrm{n}^{\mathrm{a}}$ & - & - & - & - & - & 0.8 & - & - & - & - \\
\hline
\end{tabular}

can ascertain that the basalt forming these provinces is of a common type ("oceanic flood" or "ocean plateau" basalt).

Continental flood basalts are as chemically varied as MORB. Most are light-REE-enriched and strongly enriched in LIL elements $\mathrm{K}, \mathrm{Rb}, \mathrm{Th}$, and $\mathrm{Ba}$. These features are illustrated in Figure 8, where two basalts-one from the Grande Ronde Formation of the Columbia River Province (BCR-1) and one from the Snake River Plain (US-38; Thompson et al., 1983)-are plotted relative to $\mathrm{N}$-type MORB. The ${ }^{87} \mathrm{Sr} /{ }^{86} \mathrm{Sr}$ ratios in the Columbia River basalts range from 0.7035 to 0.7080 , with enrichment in ${ }^{87} \mathrm{Sr} /{ }^{86} \mathrm{Sr}$ relative to ${ }^{143} \mathrm{Nd} /{ }^{144} \mathrm{Nd}$ on the mantle array, implying some degree of crustal assimilation (Carlson et al., 1981). The origin of the LIL-element enrichment is uncertain; either the basalts were contaminated by $\mathrm{K}$, $\mathrm{Rb}, \mathrm{Th}$, and $\mathrm{Ba}$ during assimilation of continental crust (e.g., Thompson et al., 1983), and/or the source was enriched in these elements before eruption (e.g., Weaver and Tarney, 1983).

Clearly, the Nauru Basin basalts differ from continental flood basalts, at least in terms of their LIL-element chemistry (Fig. 8). Could the Nauru basalts represent a continental flood basalt precursor, predating assimilation of continental crust? Such a suggestion would necessitate an approximately 10 -fold enrichment in $\mathrm{Rb}$,
$\mathrm{Ba}, \mathrm{K}$, and $\mathrm{Th}$, and even though such a process cannot be entirely discounted, it is considered unlikely, because some Columbia River basalts have ${ }^{87} \mathrm{Sr} /{ }^{86} \mathrm{Sr}$ ratios lower than those measured in the Nauru basalts. It is more likely that the sources of the different flood basalt provinces (whether continental or oceanic) are chemically distinct, reflecting the complex multistage histories of the evolution of their mantle sources; in continental regions, however, the story is complicated by the possibility of sialic contamination. Far more detailed investigations are required to evaluate the chemical variability between different oceanic flood provinces, in order to assess whether the variability is as extensive as that between various continental flood provinces (e.g., Thompson et al., 1983). Only after such investigations may we be in a position to assess fully the role played by source variability and sialic contamination.

\section{CONCLUSIONS}

1. Drilling at Site 462 penetrated 56 lithologic units comprising basaltic flows and, equivocally, basaltic sills, which were erupted during the interval approximately 115 to $100 \mathrm{Ma}$. They represent voluminous intraplate flood basalt activity, postdating the formation of the late Jurassic basement by some 25 to 30 m.y. 
Table 3 (continued).

\begin{tabular}{|c|c|c|c|c|c|c|c|c|c|c|c|}
\hline $\begin{array}{c}96-3,44-48 \\
{[46]}\end{array}$ & $\begin{array}{c}96-4,145-149 \\
{[46]}\end{array}$ & $\begin{array}{c}97-2,1-6 \\
{[46]}\end{array}$ & $\begin{array}{c}97-3,13-17 \\
{[46]}\end{array}$ & $\begin{array}{c}98-3,46-49 \\
{[46]}\end{array}$ & $\begin{array}{c}98-6,25-29 \\
{[46]}\end{array}$ & $\begin{array}{c}100-2,124-127 \\
{[48]}\end{array}$ & $\begin{array}{c}102-2,34-37 \\
{[48]}\end{array}$ & $\begin{array}{c}102-2,96-100 \\
{[48]}\end{array}$ & $\begin{array}{c}102-3,16-19 \\
{[48]}\end{array}$ & $\begin{array}{c}103-1,10-14 \\
{[49]}\end{array}$ & $\begin{array}{c}103-1,131-133 \\
{[50]}\end{array}$ \\
\hline 1.30 & 1.33 & 1.42 & 1.35 & 1.30 & 1.40 & 1.37 & 1.21 & 1.22 & 1.24 & 1.37 & 1.35 \\
\hline 0.07 & 0.05 & 0.07 & 0.07 & 0.07 & 0.09 & 0.05 & 0.06 & 0.06 & 0.06 & 0.06 & 0.06 \\
\hline 0.12 & 0.11 & 0.12 & 0.12 & 0.12 & 0.12 & 0.12 & 0.12 & 0.13 & 0.13 & 0.11 & 0.11 \\
\hline 91 & 101 & 99 & 99 & 97 & 97 & 93 & 93 & 97 & 93 & 91 & 90 \\
\hline 163 & 167 & 165 & 168 & 164 & 168 & 152 & 166 & 155 & 159 & 136 & 142 \\
\hline- & - & - & - & - & - & - & - & - & - & - & - \\
\hline$<1$ & $<1$ & 1 & $<1$ & $<1$ & $<1$ & 1 & $<1$ & $<1$ & 1 & $<1$ & 1 \\
\hline 96 & 91 & 95 & 95 & 94 & 95 & 93 & 95 & 95 & 95 & 96 & 96 \\
\hline 26 & 27 & 27 & 28 & 28 & 28 & 28 & 26 & 26 & 26 & 29 & 26 \\
\hline 66 & 62 & 63 & 68 & 65 & 66 & 63 & 60 & 60 & 60 & 64 & 64 \\
\hline- & - & - & 2.15 & - & - & - & - & 2.13 & - & - & - \\
\hline 4 & 4 & 4 & 5 & 4 & 5 & 5 & 4 & 4 & 5 & 4 & 5 \\
\hline- & - & - & 0.24 & - & - & - & - & 0.24 & - & - & - \\
\hline 18 & 13 & 16 & 17 & 15 & 10 & 7 & 15 & 10 & 11 & 9 & 5 \\
\hline- & - & - & 3.84 & - & - & - & - & 3.66 & - & - & - \\
\hline- & - & - & 11.46 & - & - & - & - & 11.70 & - & - & - \\
\hline- & - & - & 8.69 & - & - & - & - & 8.06 & - & - & - \\
\hline- & - & - & 2.83 & - & - & - & - & 2.72 & - & - & - \\
\hline- & - & - & 1.14 & - & - & - & - & 1.13 & - & - & - \\
\hline- & - & - & 4.23 & - & - & - & - & 4.08 & - & - & - \\
\hline- & - & - & 0.74 & - & - & - & - & 0.03 & - & - & - \\
\hline- & - & - & 0.43 & - & - & - & - & 0.42 & - & - & - \\
\hline- & - & - & 3.06 & - & - & - & - & 3.08 & - & - & - \\
\hline- & - & - & - & - & - & - & - & - & - & - & - \\
\hline- & - & - & 0.43 & - & - & - & - & 0.35 & - & - & - \\
\hline- & - & 0.011 & - & - & - & 0.011 & - & - & 0.011 & - & 0.010 \\
\hline 0.188 & 0.143 & 0.168 & 0.179 & 0.160 & 0.105 & 0.075 & 0.158 & 0.105 & 0.116 & 0.094 & 0.052 \\
\hline 0.222 & 0.308 & 0.250 & 0.294 & 0.267 & 0.500 & 0.714 & 0.267 & 0.400 & 0.455 & 0.444 & 1.000 \\
\hline- & - & - & 4.4 & - & - & - & - & 2.7 & - & - & - \\
\hline- & - & - & 0.77 & - & - & - & - & 0.92 & - & - & - \\
\hline- & - & - & 16.0 & - & - & - & - & 15.3 & - & - & - \\
\hline- & - & - & 1.79 & - & - & - & - & 1.46 & - & - & - \\
\hline- & - & - & 0.20 & - & - & - & - & 0.16 & - & - & - \\
\hline 118.1 & 128.6 & 135.1 & 119.0 & 119.9 & 127.2 & 130.4 & 120.9 & 121.9 & 123.9 & 128.3 & 126.5 \\
\hline- & - & - & 31.6 & - & - & - & - & 28.2 & - & - & - \\
\hline- & - & - & 20.8 & - & - & - & - & 16.7 & - & - & - \\
\hline 16.5 & 15.5 & 15.8 & 13.6 & 16.3 & 13.2 & 12.6 & 15.0 & 15.0 & 12.0 & 16.0 & 12.8 \\
\hline- & - & - & 1.07 & - & - & - & - & 1.02 & - & - & - \\
\hline- & - & - & 0.95 & - & - & - & - & 0.78 & - & - & - \\
\hline 1.74 & 1.90 & 1.99 & 1.76 & 1.77 & 1.88 & 1.92 & 1.78 & 1.80 & 1.83 & 1.89 & 1.87 \\
\hline- & - & - & 0.8 & - & - & - & - & 0.8 & - & - & - \\
\hline- & - & - & 0.8 & - & - & - & - & 0.8 & - & - & - \\
\hline- & - & - & 0.8 & - & - & - & - & 0.8 & - & - & - \\
\hline
\end{tabular}

2. The lithologic units can be broadly divided into three chemical units. Chemical Units $462 \mathrm{~A}-\mathrm{II}$ and $462 \mathrm{~A}$ III, from the middle and lower parts of the hole, are chemically monotonous; chemical Unit 462A-I comprises more evolved basalts having chemistries consistent with high-level fractionation of plagioclase, olivine, and minor clinopyroxene. The degree of alteration is generally slight.

3 . The style of emplacement, the duration of activity, and the eruption of large volumes of basalt with invariant composition, all compare closely with the basaltic activity recorded in major continental flood basalt provinces, for example, the Columbia River Province.

4. The Nauru Basin basalts are hy-rich tholeiites, with approximately chondritic $\mathrm{La} / \mathrm{Sm}, \mathrm{La} / \mathrm{Yb}, \mathrm{Zr} / \mathrm{Nb}, \mathrm{La} /$ $\mathrm{Ta}$, and $\mathrm{Th} / \mathrm{Hf}$ ratios. They have higher $\mathrm{La} / \mathrm{Yb}, \mathrm{Nb} / \mathrm{Zr}$, and $\mathrm{Ta} / \mathrm{Zr}$ ratios than do N-type MORB, and these are interpreted to result from fundamental differences in parental magma or even mantle source compositions. If comparisons are needed, the Nauru basalts resemble Ttype MORB from the Reykjanes Ridge, transitional (in terms of these elements) between N-type MORB and Etype MORB or ocean-island basalts.

5. The Nauru basalts have very low abundances of $\mathrm{Rb}, \mathrm{K}$, and $\mathrm{Ba}$, similar to those of N-type MORB, although their ${ }^{87} \mathrm{Sr} /{ }^{86} \mathrm{Sr}$ ratios are much higher (Fujii et al.,
1981). These ratios are considered to be primary, magmatic values.

6. The chemistry of the Nauru basalts does not compare closely with that of continental flood basalts, which tend to have far higher abundances of light REE, $\mathrm{Ba}$, $\mathrm{Rb}$, and $\mathrm{K}$, although to what extent these differences are due to sialic assimilation or source variability is unknown.

\section{ACKNOWLEDGMENTS}

I would like to thank Peter Floyd for sampling the Leg 89 cores, Giz Marriner for assistance with analyses, Brian Nimblette for sample preparation, Sheila Bishop for typing the manuscript, and Craig Hildrew for drafting the text figures. This work was supported in part by NERC Grant GR3/4022. The manuscript was reviewed and improved by $J$. Natland and R. Batiza.

\section{REFERENCES}

Batiza, R., 1981. Trace-element characteristics of Leg 61 basalts. In Larson, R. L., Schlanger, S. O., et al., Init. Repts. DSDP, 61: Washington (U.S. Govt. Printing Office), 689-695.

Batiza, R., Larson, R. L., Schlanger, S. O., Shcheka, S. A., and Tokuyama, H., 1980. Trace element abundances in basalts of Nauru Basin. Nature (London), 286:476-478.

Batiza, R., Shcheka, S., Tokuyama, H., Muehlenbachs, K., Vallier, T. L., et al., 1981. Summary and index to petrologic and geochemical studies of Leg 61 basalts. In Larson, R. L., Schlanger, S. O., et al., Init. Repts. DSDP, 61: Washington (U.S. Govt. Printing Office), 829-839. 
Table 3 (continued).

\begin{tabular}{|c|c|c|c|c|c|c|c|c|c|}
\hline $\begin{array}{l}\text { Sample (interval in } \mathrm{cm} \text { ) } \\
\text { [unit] }\end{array}$ & $\begin{array}{c}104-1,6-9 \\
{[50]}\end{array}$ & $\begin{array}{c}105-1,32-35 \\
{[52]}\end{array}$ & $\begin{array}{l}105-2,76-80 \\
{[52]}\end{array}$ & $\begin{array}{c}105-3,99-102 \\
{[52]}\end{array}$ & $\begin{array}{c}106-1,90-93 \\
{[52]}\end{array}$ & $\begin{array}{c}106-2,50-53 \\
{[52]}\end{array}$ & $\begin{array}{c}108-2,0-3 \\
{[53]}\end{array}$ & $\begin{array}{c}108 \cdot 2,99-102 \\
{[54]}\end{array}$ & $\begin{array}{c}108-3,82-85 \\
{[52]}\end{array}$ \\
\hline $\mathrm{TiO}_{2}$ & 1.37 & 1.34 & 1.33 & 1.35 & 1.29 & 1.44 & 1.33 & 1.29 & 1.37 \\
\hline $\mathrm{K}_{2} \mathrm{O}$ & 0.07 & 0.06 & 0.06 & 0.05 & 0.23 & 0.31 & 0.10 & 0.07 & 0.06 \\
\hline $\mathrm{P}_{2} \mathrm{O}_{5}$ & 0.11 & 0.11 & 0.12 & 0.12 & 0.12 & 0.13 & 0.09 & 0.12 & 0.11 \\
\hline $\mathrm{Ni}$ & 90 & 90 & 86 & 85 & 88 & 88 & 88 & 89 & 89 \\
\hline $\mathrm{Cr}$ & 137 & 144 & 135 & 135 & 139 & 144 & 114 & 148 & 122 \\
\hline $\mathrm{v}$ & - & - & - & - & - & - & - & - & - \\
\hline $\mathrm{Rb}$ & $<1$ & $<1$ & $<1$ & $<1$ & 3 & 2 & $<1$ & $<1$ & $<1$ \\
\hline $\mathrm{Sr}$ & 94 & 96 & 95 & 96 & 93 & 93 & 92 & 95 & 94 \\
\hline $\mathbf{Y}$ & 28 & 28 & 27 & 27 & 27 & 26 & 31 & 28 & 30 \\
\hline $\mathrm{Zr}$ & 64 & 64 & 63 & 63 & 62 & 63 & 66 & 63 & 65 \\
\hline $\mathrm{Hf}$ & - & - & - & - & - & - & - & - & - \\
\hline $\mathrm{Nb}$ & 4 & 5 & 4 & 5 & 4 & 4 & 5 & 4 & 4 \\
\hline Ta & - & - & - & - & - & - & - & - & - \\
\hline $\mathrm{Ba}$ & 7 & 11 & 9 & 9 & 15 & 16 & 12 & 8 & 13 \\
\hline $\mathrm{La}$ & - & - & - & - & - & - & - & - & - \\
\hline $\mathrm{Ce}$ & - & - & - & - & - & - & - & - & - \\
\hline $\mathrm{Nd}$ & - & - & - & - & - & - & - & - & - \\
\hline Sm & - & - & - & - & - & - & - & - & - \\
\hline $\mathrm{Eu}$ & $\bar{z}$ & $=$ & $\overline{-}$ & $=$ & $=$ & $=$ & $\overline{-}$ & $\overline{-}$ & $\overline{-}$ \\
\hline Gd & - & - & - & $\bar{z}$ & $\bar{z}$ & 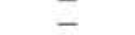 & - & - & - \\
\hline $\mathrm{Tb}$ & - & - & - & $=$ & - & - & - & - & - \\
\hline $\mathrm{Tm}$ & - & - & - & - & - & - & - & - & - \\
\hline $\mathrm{Yb}$ & - & - & - & - & - & - & - & - & - \\
\hline Lu & - & $=$ & $=$ & $=$ & $=$ & $=$ & $=$ & - & - \\
\hline Th & - & - & - & - & - & - & - & - & - \\
\hline
\end{tabular}

Element ratios

\begin{tabular}{|c|c|c|c|c|c|c|c|c|c|}
\hline $\mathrm{Rb} / \mathrm{Sr}$ & - & - & - & - & 0.032 & 0.022 & - & - & - \\
\hline $\mathrm{Ba} / \mathrm{Sr}$ & 0.074 & 0.115 & 0.095 & 0.094 & 0.161 & 0.172 & 0.130 & 0.084 & 0.138 \\
\hline $\mathrm{Nb} / \mathrm{Ba}$ & 0.571 & 0.455 & 0.444 & 0.556 & 0.267 & 0.250 & 0.417 & 0.500 & 0.308 \\
\hline $\mathrm{Ba} / \mathrm{La}$ & - & - & - & - & - & - & - & - & - \\
\hline $\mathrm{La} / \mathrm{Nb}$ & - & - & $\overline{-}$ & $=$ & $=$ & - & $=$ & - & - \\
\hline $\mathrm{La} / \mathrm{Ta}$ & - & - & - & - & - & - & - & - & - \\
\hline $\mathrm{Th} / \mathrm{Ta}$ & - & - & - & - & - & - & - & - & - \\
\hline $\mathrm{Th} / \mathrm{Hf}$ & - & - & - & - & - & - & - & - & - \\
\hline $\mathrm{Ti} / \mathrm{Zr}_{\mathrm{r}}$ & 128.3 & 125.5 & 126.6 & 128.5 & 124.7 & 137.0 & 120.8 & 122.7 & 126.4 \\
\hline $\mathrm{Zr} / \mathrm{Hf}$ & - & - & - & - & - & - & - & - & - \\
\hline $\mathrm{Nb} / \mathrm{Ta}$ & - & - & - & - & - & - & - & - & $=$ \\
\hline $\mathrm{Zr} / \mathrm{Nb}$ & 16.0 & 12.8 & 15.8 & 12.6 & 15.5 & 15.8 & 13.2 & 15.8 & 16.3 \\
\hline$(\mathrm{La} / \mathrm{Ta}) \mathrm{n}^{\mathrm{a}}$ & - & - & - & - & - & - & - & - & - \\
\hline (Th/Hf) $\mathrm{n}^{\mathrm{a}}$ & -89 & 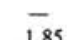 & - & $\overline{10}$ & $\overline{184}$ & $\overline{200}$ & - & - & - \\
\hline $\begin{array}{l}(\mathrm{Ti} / \mathrm{Zr}) \mathrm{n}^{\mathrm{a}} \\
(\mathrm{La} / \mathrm{Y}) \mathrm{n}^{\mathrm{a}}\end{array}$ & 1.89 & 1.85 & 1.87 & 1.90 & 1.84 & 2.02 & 1.78 & 1.81 & 1.86 \\
\hline$(\mathrm{La} / \mathrm{Yb}) \mathrm{n}^{\mathrm{a}}$ & z & $\bar{z}$ & $\overline{-}$ & $\bar{z}$ & $\overline{-}$ & $\bar{z}$ & $\overline{-}$ & $\overline{-}$ & $\overline{-}$ \\
\hline$(\mathrm{La} / \mathrm{Sm}) \mathrm{n}^{\mathrm{a}}$ & - & - & - & - & - & - & - & - & - \\
\hline
\end{tabular}

Bence, A. E., Papike, J. J., and Ayuso, R. A., 1975. Petrology of submarine basalts from the central Caribbean: DSDP Leg 15. J. Geophys. Res., 80:4775-4804.

Bougault, H., Cambon, P., Joron, J.-L., and Treuil, M., 1979. Trace elements: Fractional crystallization and partial melting process, heterogeneity of upper mantle material. In Dmitriev, L., Heirtzler, J., et al., Init. Repts. DSDP, 46: Washington (U.S. Govt. Printing Office), 215-226.

Bougault, H., Joron, J.-L., and Treuil, M., 1980. The primordial chondritic nature and large-scale heterogeneities in the mantle: Evidence from high and low partition coefficient elements in oceanic basalts. Philos. Trans. R. Soc. London, Ser. A, 297:203-213.

Bougault, H., Treuil, M., and Joron, J.-L., 1979. Trace elements in basalts from $23^{\circ} \mathrm{N}$ and $36^{\circ} \mathrm{N}$ in the Atlantic Ocean: Fractional crystallization, partial melting, and heterogeneity of the upper mantle. In Melson, W. G., Rabinowitz, P. D., et al., Init. Repts. DSDP, 45: Washington (U.S. Govt. Printing Office), 493-506.

Carlson, R. W., Lugmair, G. W., and MacDougall J. D., 1981. Columbia River volcanism: The question of mantle heterogeneity or crustal contamination. Geochim. Cosmochim. Acta, 45:2483-2500.

Chayes, F., 1972. Silica saturation in Cenozoic basalt. Philos. Trans. R. Soc. London, A271:285-296.

Curray, J. R., Moore, D. G., et al., 1982. Init. Repts. DSDP, 64: Washington (U.S. Govt. Printing Office).

DePaolo, D. J., and Wasserburg, G. J., 1979. Neodymium isotopes in flood basalts from the Siberian Platform and inferences about their mantle sources. Proc. Nat. Acad. Sci., 76:3056-3060.

Dick, H. J. B., 1977. Partial melting in the Josephine Peridotite. I. The effect of mineral composition and its consequences for geobarometry and geothermometry. Am. J. Sci., 277:801-832.
Einsele, G., Gieskes, J. M., Curray, J. R., et al., 1980. Intrusion of basaltic sills into highly porous sediments, and resulting hydrothermal activity. Nature, 283:441-445.

Flanagan. F. J., 1973. 1972 values for international geochemical reference samples. Geochim. Cosmochim. Acta, 37:1189-1200.

Fujii, N., Notsu, K., and Onuma, N., 1981. Chemical composition and $\mathrm{Sr}$ isotopes of Deep Sea Drilling Project Leg 61 basalts. In Larson, R. L., Schlanger, S. O., et al., Init. Repts. DSDP, 61: Washington (U.S. Govt. Printing Office), 697-700.

Gast, P. W., 1968. Trace element fractionation and the origin of tholeiitic and alkaline magma types. Geochim. Cosmochim. Acta, 32: 1057-1086.

Green, D. H., 1971. Composition of basaltic magmas as indicators of conditions of origin: Application to oceanic volcanism. Philos. Trans. R. Soc. London, A268:707-725.

Hart, S. R., Erlank, A. J., and Kable, E. J. D., 1974. Seafloor basalt alteration: Some chemical and strontium isotopic effects. Contrib. Mineral. Petrol., 44:219-230.

Hole, M. J., Saunders, A. D., Marriner, G. F., and Tarney, J., 1984. Subduction of pelagic sediments: Implications for the origin of Ce-anomalous basalts from the Mariana Islands. J. Geol. Soc. London, 141:453-472.

Joron, J.-L., Bougault, H., Maury, R. C., Bohn, M., and Desprairies, A., 1984. Strongly depleted tholeiites from the Rockall Plateau Margin, North Atlantic: Geochemistry and mineralogy. In Roberts, D. G., Schnitker, D., et al., Init. Repts. DSDP, 81: Washington (U.S. Govt. Printing Office), 783-794.

Joron, J-L., Briqueu, L., Bougault, H., and Treuil, M., 1980. East Pacific Rise, Galapagos Spreading Center and Siqueiros Fracture Zone, Deep Sea Drilling Project Leg 54: Hygromagmaphile ele- 
ments-a comparison with the North Atlantic. In Rosendahl, B. R., Hekinian, R., et al., Init. Repts. DSDP, 54: Washington (U.S. Govt. Printing Office), 725-736.

Kay, R. W., Hubbard, N. J., and Gast, P. W., 1970. Chemical characteristics of oceanic ridge volcanic rocks. J. Geophys. Res., 75: 1585-1613.

Larson, R. L., and Schlanger, S. O., 1981. Geological evolution of the Nauru Basin, and regional implications. In Larson, R. L., Schlanger, S. O., et al., Init. Repts. DSDP, 61: Washington (U.S. Govt. Printing Office), 841-862.

Larson, R. L., Schlanger, S. O., et al., 1978. Volcanic complex found in the west-central Pacific. Geotimes, 23:21-24.

1981. Init. Repts. DSDP, 61: Washington (U.S. Govt. Printing Office).

Lewis, B. T. R., Robinson, P., et al., 1983. Init. Repts. DSDP, 65: Washington (U.S. Govt. Printing Office).

Moberly, R., and Jenkyns, H. C., 1981. Cretaceous volcanogenic sediments of the Nauru Basin, Deep Sea Drilling Project Leg 61. In Larson R. L., Schlanger, S. O., et al., Init. Repts. DSDP, 61; Washington (U.S. Govt. Printing Office), 533-548.

Natland, J. H., Menard, H. W., and Leg 91 Scientific Party, 1983. Old ocean crust in the Southwest Pacific: volcanism, hydrothermal processes, and sedimentary history revealed by DSDP Leg 91 coring. EOS, 64:315

Natland, J., et al., in press. Init. Repts. DSDP, 91: Washington (U.S. Govt. Printing Office).

O'Hara, M. J., 1973. Non-primary magmas and the dubious mantle plume beneath Iceland. Nature, 243:507-508.

O'Nions, R. K., Evensen, N. M., and Hamilton, P. J., 1979. Geochemical modelling of mantle differentiation and crustal growth. J. Geophys. Res., 84:6091-6101.

O'Nions, R. K., Hamilton, P. J., and Evensen, N. M., 1977. Variations ${ }^{143} \mathrm{Nd} /{ }^{144} \mathrm{Nd}$ and ${ }^{87} \mathrm{Sr} /{ }^{86} \mathrm{Sr}$ ratios in oceanic basalts. Earth Planet. Sci. Lett., 34:13-22.

Ozima, M., Saito, K., and Takigami, Y., 1981. ${ }^{40} \mathrm{Ar}-{ }^{39} \mathrm{Ar}$ geochronological studies on rocks drilled at Holes 462 and 462A, Deep Sea Drilling Project Leg 61. In Larson, R. L., Schlanger, S. O., et al., Init. Repts. DSDP, 61: Washington (U.S. Govt. Printing Office), 701-703.

Pearce, J. A., and Cann, J. R., 1973. Tectonic setting of basic volcanic rocks using trace element analyses. Earth Planet. Sci. Lett., 19: 290-300.

Saunders, A. D., 1983. Geochemistry of basalts recovered from the Gulf of California during Leg 65 of the Deep Sea Drilling Project. In Lewis, B. T. R., Robinson, P., et al., Init. Repts. DSDP, 65: Washington (U.S. Govt. Printing Office), 591-621.

Saunders, A. D., and Tarney, J., 1984. The geochemical characteristics of basaltic volcanism within back-arc basins. In Kokelaar, B. P., and Howells, M. F. (Eds.), Marginal Basin Geology. Geol. Soc. London Spec. Publ., 16:59-76.

Saunders, A. D., Tarney, J., Stern, C. R., and Dalziel, I. W. D., 1979. Geochemistry of Mesozoic marginal basin floor igneous rocks from southern Chile. Geol. Soc. Am. Bull., 90:237-258.

Schilling, J.-G., 1975. Rare-earth variations across "normal segments" of the Reykjanes Ridge, $60-53^{\circ} \mathrm{N}$, Mid-Atlantic Ridge, $29^{\circ} \mathrm{S}$, and East Pacific Rise, $2-19^{\circ} \mathrm{S}$, and evidence of the composition of the underlying low velocity layer. J. Geophys. Res., 80:1459-1473.

Schlanger, S. O., and Silva, I. P., 1981. Tectonic, volcanic, and paleogeographic implications of redeposited reef faunas of Late Cretaceous and Tertiary age from the Nauru Basin and Line Islands. In Larson, R. L., Schlanger, S. O., et al., Init. Repts. DSDP, 61: Washington (U.S. Govt. Printing Office), 817-827.

Shcheka, S., 1981. Igneous Rocks of Deep Sea Drilling Project Leg 61, Nauru Basin. In Larson, R. L., Schlanger, S. O., et al., Init. Repts. DSDP, 61: Washington (U.S. Govt. Printing Office), 633-646.

Simoneit, B. R. T., and Philip, R. P., 1982. Organic geochemistry of lipids and kerogen and the effects of basalt intrusion on unconsolidated oceanic sediments: Sites 477, 478 and 481. Guaymas Basin, Gulf of California. In Curray, J. R., Moore, D. G., et al., Init. Repts. DSDP, 64: Washington (U.S. Govt. Printing Office), 883-904.
Stern, C. R., and Elthon, D., 1979. Vertical variations in the effects of hydrothermal metamorphism in Chilean ophiolites: Their implications for ocean floor metamorphism. Tectonophysics, 55:179-213.

Sun, S.-S., and Nesbitt, R. W., 1977. Chemical heterogeneity of the Archaean mantle, chemical composition of the Earth, and mantle evolution. Earth Planet. Sci. Lett., 35:429-448.

Sun, S.-S., Nesbitt, R. W., and Sharaskin, A. Y., 1979. Geochemical characteristics of mid-ocean ridge basalts. Earth Planet. Sci. Lett., 44:119-138.

Swanson, D. A., and Wright, T. L., 1978. Bedrock geology of the northern Columbia Plateau and adjacent areas. In Baker, V. R., and Nummendahl, D. (Eds.), The Channeled Scablands, NASA Office of Space Science, Planetary Geology Program, pp. 37-57.

Swanson, D. A., Wright, T. L., Hooper, P. R., and Bentley, R. D., 1979. Revisions in stratigraphic nomenclature of the Columbia River Basalt Group. U.S. Geol. Surv. Bull., 1457G:G1-G59.

Tarney, J., Saunders, A. D., Weaver, S. D., Donnellan, N. C. B., and Hendry, G. L., 1979. Minor-element geochemistry of basalts from Leg 49, North Atlantic Ocean. In Luyendyk, B. P., Cann, J. R., et al., Init. Repts. DSDP, 49: Washington (U.S. Govt. Printing Office), 657-691.

Tarney, J., Wood, D. A., Saunders, A. D., Cann, J. R., and Varet, J., 1980. Nature of mantle heterogeneity in the North Atlantic: Evidence from deep sea drilling. Philos. Trans. R. Soc. London, A297: 179-202.

Thompson, G., Bryan, W. B., Frey, F. A., Dickey, J. S., and Suen, C. J., 1976. Petrology and geochemistry of basalts from DSDP Leg 34, Nazca Plate. In Yeats, R. S., Hart, S, R., et al., Init. Repts. DSDP, 34: Washington (U.S. Govt. Printing Office), 215-226.

Thompson, I. D., Brassell, C. D., Comet, P. A., Eglinton, G., Isaacson, P. J., et al., 1981. Preliminary lipid analyses of Cores 49, 54, and 59 from Hole 462. In Larson, R. L., Schlanger, S. O., et al., Init. Repts. DSDP, 61: Washington (U.S. Govt. Printing Office), 613-618.

Thompson, R. N., Morrison, M. A., Dickin, A. P., and Hendry, G. L., 1983. Continental flood basalts...AArachnids rule OK? In Hawkesworth, C. J., and Norry, M. J. (Eds.), Continental Flood Basalts: Cheshire, England (Shiva Publishing), pp. 159-185.

Tokuyama, H., and Batiza, R., 1981. Chemical composition of igneous rocks and origin of sill and pillow-basalt complex of Nauru Basin, southwest Pacific. In Larson, R. L., Schlanger, S. O., et al., Init. Repts. DSDP, 61: Washington (U.S. Govt. Printing Office), 673683.

Weaver, B. L., and Tarney, J., 1983. Chemistry of the sub-continental mantle: Inferences from Archaean and Proterozoic dykes and continental flood basalts. In Hawkesworth, C. J., and Norry, M. J. (Eds.), Continental Flood Basalts: Cheshire, England (Shiva Publishing), pp. 209-229.

Windom, K. E., and Book, P., 1981. Vein minerals in basalt, Hole 462A, Leg 61 of the Deep Sea Drilling Project. In Larson, R. L., Schlanger, S. O., et al., Init. Repts. DSDP, 61: Washington (U.S. Govt. Printing Office), 647-652.

Winterer, E. L., 1976. Bathymetry and regional tectonic setting of the Line Island Chain. In Schlanger, S. O., Jackson, E. D., et al., Init. Repts. DSDP, 33: Washington (U.S. Govt. Printing Office), 731-748.

Wood, D. A., Tarney, J., Varet, J., Saunders, A. D., Bougault, H., et al., 1979. Geochemistry of basalts drilled in the North Atlantic by IPOD Leg 49: Implications for mantle heterogeneity. Earth Planet. Sci. Lett., 42:77-97.

Wood, D. A., Tarney, J., and Weaver, B. L., 1981. Trace element variations in Atlantic Ocean basalts and Proterozoic dykes from northwest Scotland: Their bearing upon the nature and geochemical evolution of the upper mantle. Tectonophysics, 75:91-112.

Wood, D. A., Varet, J., Bougault, H., et al., 1979. The petrology, geochemistry, and mineralogy of North Atlantic basalts: A discussion based on IPOD Leg 49. In Luyendyk, B. P., Cann, J. R., et al., Init. Repts. DSDP, 49: Washington (U.S. Govt. Printing Office), 597-655.

Date of Initial Receipt: 16 December 1983

Date of Acceptance: 14 June 1984 


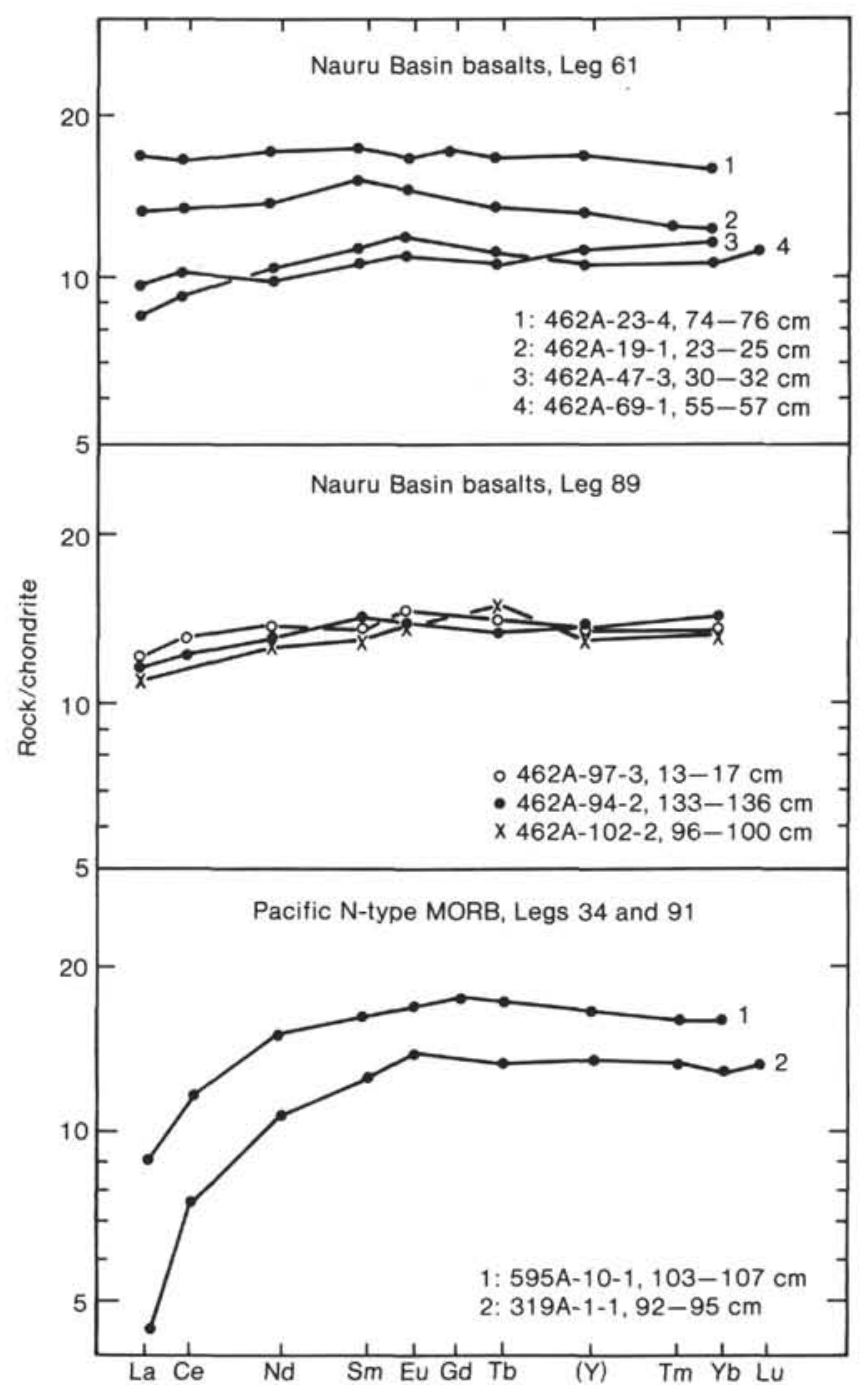

Figure 4. Chondrite-normalized REE patterns for Nauru Basin basalts, Legs 61 and 89. For comparative purposes, normal or N-type MORB from the Nazca Plate (Hole 319A) and Jurassic crust, SW Pacific (Hole 595A), are also plotted. Data for N-type MORB previously unpublished. 


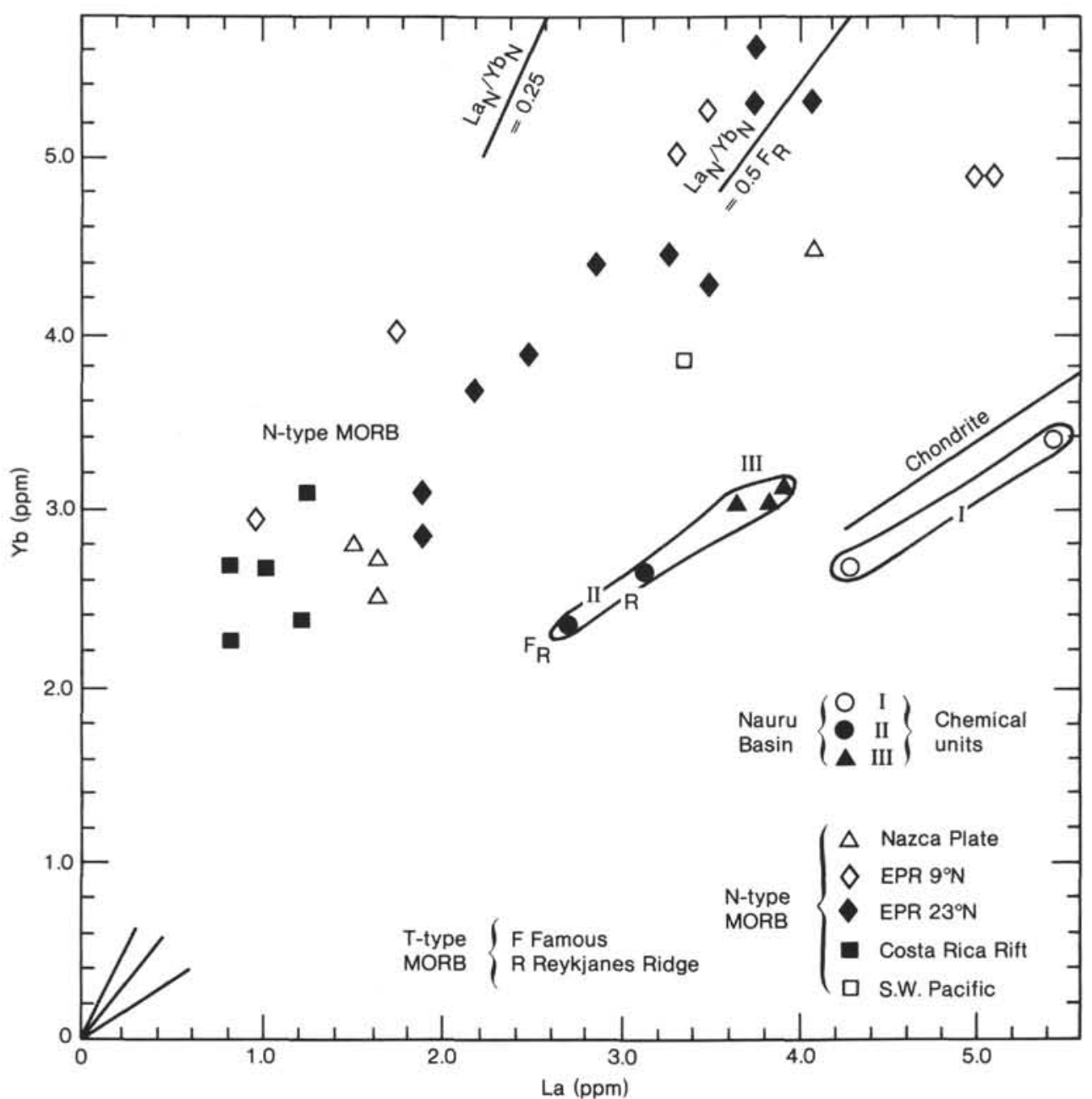

Figure 5. Yb versus La for Nauru Basin basalts and for N-type and T-type MORB. Data sources: Leg 34 (Nazca Plate), Leg 54 (EPR 9 ${ }^{\circ} \mathrm{N}$ ), Leg 69 (Costa Rica Rift), and Leg 91 (SW Pacific Jurassic crust) from A. D. Saunders, unpublished data; Leg 49 (Reykjanes Ridge and FAMOUS) from Wood, Tarney, et al. (1979); Leg $65\left(\right.$ EPR $\left.23^{\circ} \mathrm{N}\right)$ from Saunders (1983). 


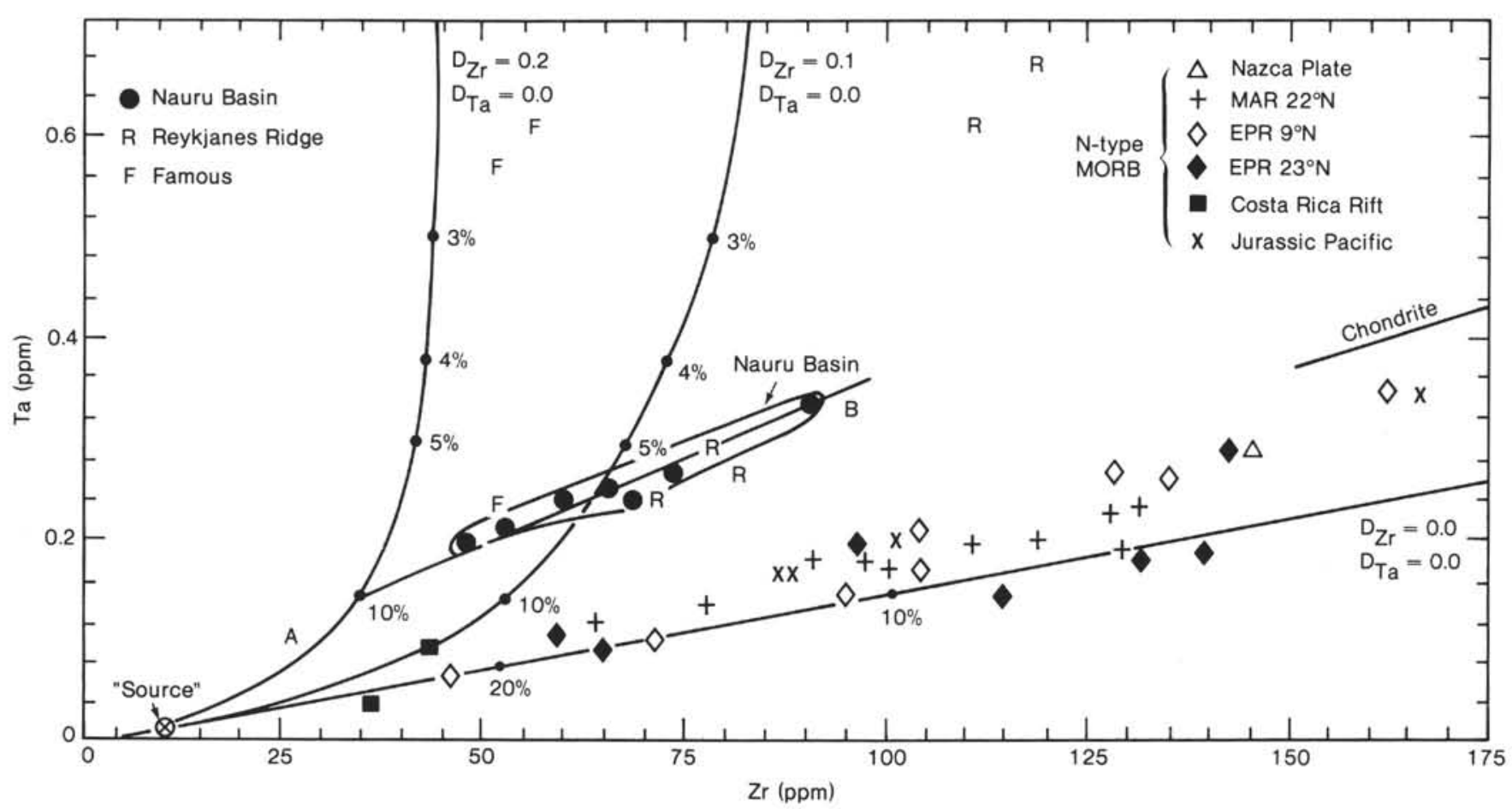

Figure 6. Ta versus $\mathrm{Zr}$ for Nauru Basin basalts and for MORB. Two partial melting curves are included for diagrammatic purposes, to illustrate that it is theoretically possible to derive Nauru Basin $\mathrm{Ta} / \mathrm{Zr}$ ratios from the same source as $\mathrm{N}$-type MORB, provided that the bulk distribution coefficient (D) for $\mathrm{Zr}$ is sufficiently high, and that $\mathrm{D}_{\mathrm{Ta}}$ approaches zero. Thus, $10 \%$ partial melting of source material with $0.015 \mathrm{ppm} \mathrm{Ta}, 10 \mathrm{ppm} \mathrm{Zr}$, and with $\mathrm{D}_{\mathrm{Zr}}=0.2$ (curve $\mathrm{A}$ ), followed by high-level fractionation with $\mathrm{D}_{\mathrm{Zr}} \sim 0.0, \mathrm{D}_{\mathrm{Ta}} \sim 0.0$ (line $\mathrm{B}$ ), could produce the Ta/Zr ratio of Nauru Basin basalts from an N-type MORB source. For reasons given in the text, however, this is considered unlikely. Data sources as for Figure 5, plus data for Legs $45 / 46$ (MAR $22^{\circ} \mathrm{N}$ ) from Bougault, Treuil, et al. (1979) and Bougault, Cambon, et al. (1979).

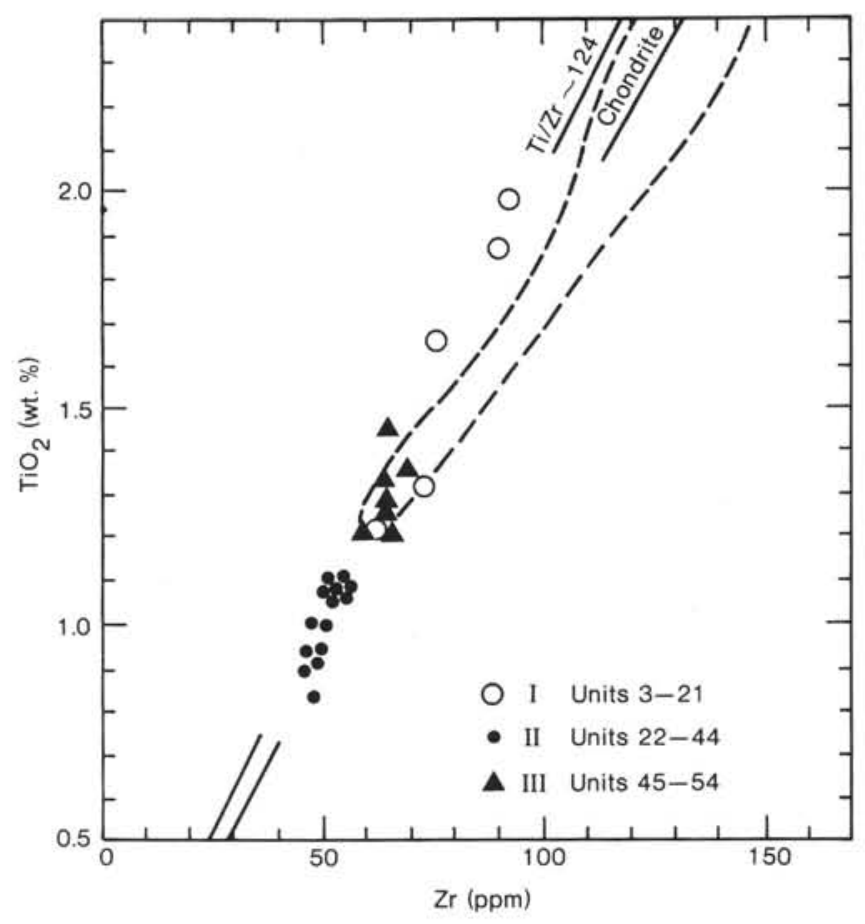

Figure 7. $\mathrm{TiO}_{2}$ versus $\mathrm{Zr}$ for Nauru Basin basalts. Dashed line indicates field of N-type MORB from EPR $9^{\circ} \mathrm{N}$ (Saunders 1983). Chondrite $=$ chondritic ratio $(\mathrm{Ti} / \mathrm{Zr}=110)$ from Sun and Nesbitt (1977). 
Table 4. Nauru Basin basalts and comparative data.

\begin{tabular}{|c|c|c|c|c|c|c|c|c|}
\hline & \multicolumn{3}{|c|}{ Nauru Basin ${ }^{a}$} & \multicolumn{3}{|c|}{ N-type MORB ${ }^{b}$} & \multirow{2}{*}{$\begin{array}{c}\mathrm{RR}^{\mathrm{c}} \\
409-3\end{array}$} & \multirow{2}{*}{$\begin{array}{l}\text { CFB } \\
\text { US- } 38\end{array}$} \\
\hline & I & II & III & $319 \mathrm{~A}$ & 321 & $595 \mathrm{~B}$ & & \\
\hline $\mathrm{SiO}_{2}$ & 49.0 & 49.6 & 49.7 & 50.5 & 49.1 & 49.8 & 49.3 & 47.7 \\
\hline $\mathrm{TiO}_{2}$ & 1.99 & 0.95 & 1.35 & 1.24 & 2.73 & 1.86 & 1.74 & 2.10 \\
\hline $\mathrm{Al}_{2} \mathrm{O}_{3}$ & 14.6 & 14.9 & 14.4 & 14.8 & 12.6 & 14.5 & 14.0 & 15.5 \\
\hline $\mathrm{Fe}_{2} \mathrm{O}_{3} \mathrm{e}^{\mathrm{e}}$ & 1.64 & 1.42 & 1.62 & $\begin{array}{l}14.0 \\
1.17\end{array}$ & $\begin{array}{l}1.74 \\
1.74\end{array}$ & 1.45 & 1.44 & 1.55 \\
\hline $\mathrm{FeO}^{\mathrm{e}^{3}}$ & 10.91 & 9.44 & 10.81 & 7.79 & 11.57 & 9.66 & 9.62 & 10.33 \\
\hline $\mathrm{MnO}$ & 0.21 & 0.22 & 0.21 & 0.18 & 0.23 & 0.24 & 0.19 & 0.18 \\
\hline $\mathrm{MgO}$ & 6.83 & 7.56 & 7.05 & 7.77 & 6.16 & 6.64 & 8.09 & 7.92 \\
\hline $\mathrm{CaO}$ & 10.87 & 12.74 & 11.61 & 12.54 & 10.95 & 10.80 & 11.65 & 10.77 \\
\hline $\mathrm{Na}_{2} \mathrm{O}$ & 2.62 & 2.00 & 2.46 & 2.41 & 2.40 & 2.89 & 2.30 & 2.57 \\
\hline $\mathrm{K}_{2} \mathrm{O}$ & 0.10 & 0.05 & 0.07 & 0.14 & 0.20 & 0.71 & 0.18 & 0.81 \\
\hline $\mathrm{P}_{2} \mathrm{O}_{5}$ & 0.17 & 0.07 & 0.10 & 0.09 & 0.20 & 0.15 & 0.22 & 0.45 \\
\hline Total & 98.99 & 99.00 & 99.33 & 98.68 & 97.85 & 98.69 & 98.74 & 99.92 \\
\hline $\mathrm{Mg} \mathrm{no}^{\mathrm{e}}$ & 52.7 & 58.8 & 53.8 & 64.0 & 48.7 & 55.1 & 60.0 & 57.8 \\
\hline
\end{tabular}

Trace elements (ppm)

$\begin{array}{lcccccccc}\mathrm{Ni} & 103 & 168 & 99 & 153 & 57 & 61 & 98 & 89 \\ \mathrm{Cr} & 188 & 484 & 154 & 277 & 128 & 183 & 330 & 254 \\ \mathrm{Rb} & 1 & 1 & <1 & 2 & 3 & 12 & 3 & 15 \\ \mathrm{Sr} & 125 & 83 & 95 & 101 & 92 & 110 & 101 & 352 \\ \mathrm{Y} & 40 & 23 & 28 & 28 & 53 & 38 & 35 & 31 \\ \mathrm{Zr} & 90 & 47 & 68 & 61 & 145 & 101 & 110 & 168 \\ \mathrm{Hf} & 2.60 & 1.52 & 2.15 & 1.71 & 4.17 & 2.95 & 3.10 & 3.66 \\ \mathrm{Nb} & 7 & 4 & 5 & 1 & 7 & 4 & 12 & 15 \\ \mathrm{Ta} & 0.34 & 0.20 & 0.24 & - & 0.29 & 0.20 & 0.68 & 1.01 \\ \mathrm{Ba} & 25 & 7 & 17 & 7 & 38 & 26 & 70 & 405 \\ \mathrm{La} & 5.45 & 3.11 & 3.84 & 1.66 & 5.96 & 3.34 & 6.10 & 17.60 \\ \mathrm{Ce} & 13.90 & 8.85 & 11.46 & 5.85 & 18.40 & 12.68 & 18.60 & 42.70 \\ \mathrm{Nd} & 10.95 & 6.16 & 8.69 & 6.59 & 17.44 & 11.37 & 13.90 & 23.40 \\ \mathrm{Sm} & 3.49 & 2.19 & 2.83 & 2.72 & 6.23 & 3.93 & 4.71 & 5.40 \\ \mathrm{Eu} & 1.28 & 0.86 & 1.14 & 1.05 & 2.12 & 1.44 & 1.59 & 1.91 \\ \mathrm{Gd} & 4.85 & 3.21 & 4.23 & - & - & 5.13 & 5.30 & 5.50 \\ \mathrm{~Tb} & 0.87 & 0.57 & 0.74 & 0.69 & 1.51 & 0.99 & 0.97 & - \\ \mathrm{Tm} & 0.59 & - & 0.43 & 0.47 & 1.01 & 0.59 & 0.60 & - \\ \mathrm{Yb} & 3.40 & 2.64 & 3.06 & 2.67 & 6.34 & 3.82 & 3.94 & 2.38 \\ \mathrm{Lu} & 0.59 & 0.43 & - & 0.45 & 1.03 & - & 0.67 & 0.35 \\ \mathrm{Th} & 0.53 & 0.26 & 0.43 & - & 0.33 & 0.27 & 0.59 & 1.09\end{array}$

Element ratios

$\begin{array}{lcccccccc}\mathrm{Rb} / \mathrm{Sr} & 0.008 & 0.012 & - & 0.020 & 0.033 & 0.109 & 0.030 & 0.043 \\ \mathrm{Ba} / \mathrm{Sr} & 0.200 & 0.084 & 0.179 & 0.069 & 0.413 & 0.236 & 0.693 & 1.151 \\ \mathrm{Nb} / \mathrm{Ba} & 0.280 & 0.571 & 0.294 & 0.143 & 0.184 & 0.154 & 0.171 & 0.037 \\ \mathrm{Ba} / \mathrm{La} & 4.6 & 2.3 & 4.4 & 4.2 & 6.4 & 7.8 & 11.5 & 23.0 \\ \mathrm{La} / \mathrm{Nb} & 0.78 & 0.78 & 0.77 & 1.66 & 0.85 & 0.83 & 0.51 & 1.17 \\ \mathrm{La} / \mathrm{Ta} & 16.0 & 15.5 & 16.0 & - & 20.6 & 16.7 & 9.0 & 17.4 \\ \mathrm{Th} / \mathrm{Ta} & 1.56 & 1.30 & 1.79 & - & 1.14 & 1.35 & 0.87 & 1.08 \\ \mathrm{Th} / \mathrm{Hf} & 0.20 & 0.17 & 0.20 & - & 0.08 & 0.09 & 0.19 & 0.30 \\ \mathrm{Ti} / \mathrm{Zr} & 132.6 & 121.2 & 119.0 & 121.9 & 112.9 & 110.4 & 94.8 & 74.9 \\ \mathrm{Zr} / \mathrm{Hf} & 34.6 & 30.9 & 31.6 & 35.7 & 34.8 & 34.2 & 35.5 & 45.9 \\ \mathrm{Zr} / \mathrm{Nb} & 12.9 & 11.8 & 13.6 & 61.0 & 20.7 & 25.3 & 9.2 & 11.2 \\ (\mathrm{La} / \mathrm{Ta}){ }^{\mathrm{f}} & 1.08 & 1.04 & 1.07 & - & 1.38 & 1.12 & 0.60 & 1.17 \\ (\mathrm{Th} / \mathrm{Hf}) \mathrm{f} & 0.97 & 0.81 & 0.95 & - & 0.38 & 0.43 & 0.90 & 1.41 \\ (\mathrm{Ti} / \mathrm{Zr}) \mathrm{f}^{\mathrm{f}} & 1.96 & 1.79 & 1.76 & 1.80 & 1.67 & 1.63 & 1.40 & 1.11 \\ (\mathrm{La} / \mathrm{Yb}) \mathrm{f}^{\mathrm{f}} & 1.1 & 0.8 & 0.8 & 0.4 & 0.6 & 0.6 & 1.0 & 5.0 \\ (\mathrm{La} / \mathrm{Sm}) \mathrm{f}^{\mathrm{f}} & 1.0 & 0.9 & 0.8 & 0.4 & 0.6 & 0.5 & 0.8 & 2.0\end{array}$

Note: Major element oxides in wt. \%.

${ }^{a}$ I: Sample 462A-23-4, 74-76 cm. II: Sample 462A-47-3, 30-33 cm. III: Sample 462A-101-5, 19-25 cm.

b Previously unpublished analyses. 319A (Leg 34): Sample 319A-1-1, 130-133 cm (Nazca Plate). 321 (Leg 34): Sample 321-14-1, 144-146 cm (Nazca Plate). 595B (Leg 91): Sample 595B-7-2, 80-82 cm (SW Pacif-

ic Jurassic crust).

${ }^{c}$ Reykjanes Ridge (RR) T-type MORB (Wood, Tarney, et al., 1979). 409-3 (Leg 49): Sample 409-24-2, $87-90 \mathrm{~cm}$.

d Continental flood basalt (CFB) (Thompson et al., 1983), Snake River Plain.

${ }^{\mathrm{e}}$ Calculated from an assumed $\mathrm{Fe}_{2} \mathrm{O}_{3} / \mathrm{FeO}$ ratio of 0.15 .

$\mathrm{f} \mathrm{n}$ indicates chondrite-normalized ratio. 


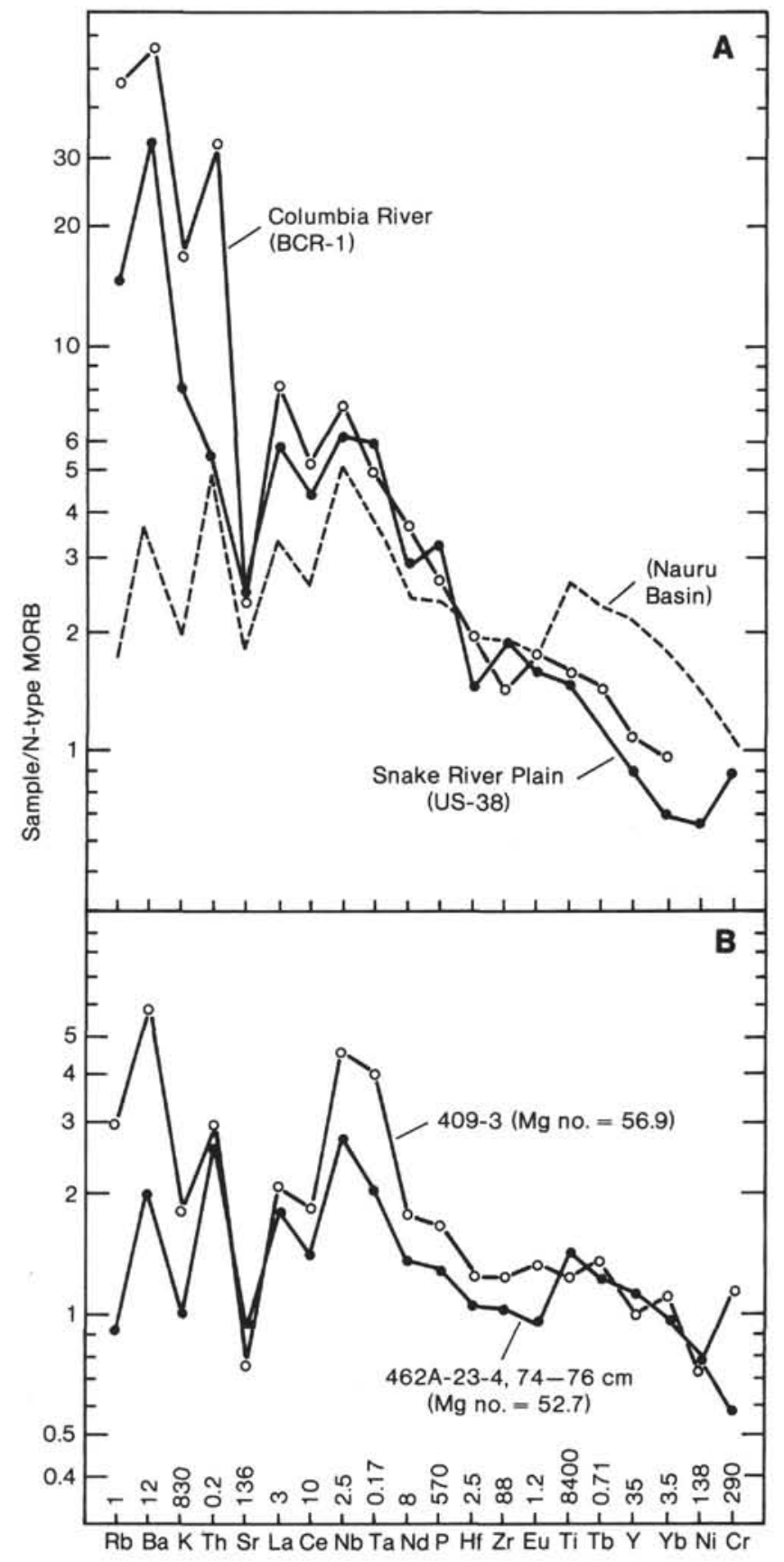

Figure 8. Multi-element diagram, with data normalized against $\mathrm{N}$-type MORB (Saunders and Tarney, 1984). Continental flood basalts: A. Columbia River (BCR-1) (Flanagan, 1973, and A. D. Saunders, unpublished data) and Snake River Plain (US 38) (Thompson et al., 1983). B. Nauru Basin and Reykjanes Ridge (Wood, Tarney, et al., 1979) basalts. Dashed line in A represents Nauru Basin basalt normalized to same $\mathrm{Zr}$ value as BCR-1. $\mathrm{Mg}$ number $=100 \mathrm{Mg}$ / $\mathrm{Mg}+\mathrm{Fe})$. 


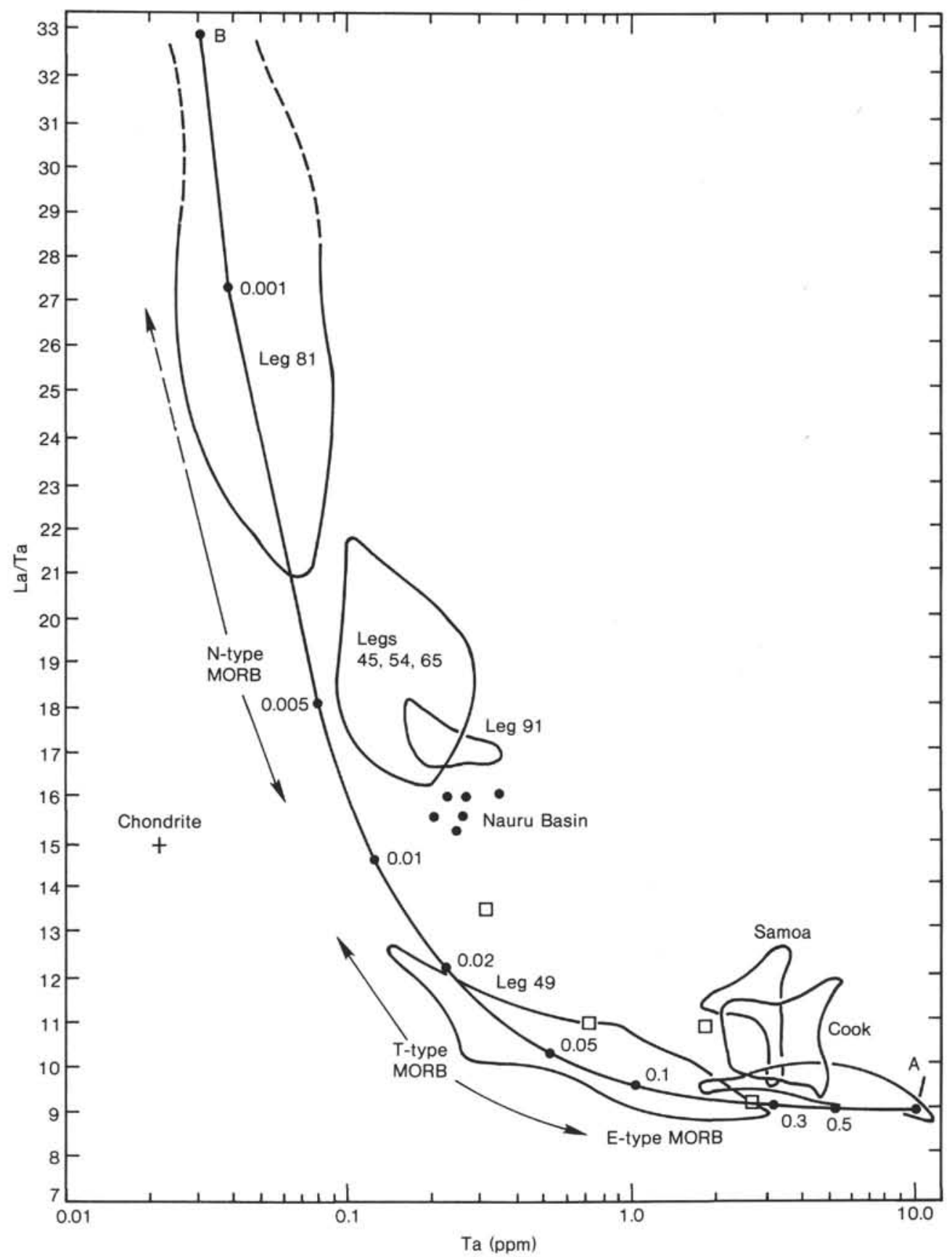

Figure 9. La/Ta ratio versus Ta for Pacific and Atlantic oceanic basalts ( $\mathrm{Ni}>100 \mathrm{ppm}$ ), partly to illustrate the transitional chemistry of the Nauru Basin basalts. Data sources: Leg 81, Joron et al. (1984), Leg 45, Bougault, Treuil, et al. (1979); Leg 65, Saunders (1983); Leg 49, Wood, Varet, et al. (1979), Wood, Tarney, et al. (1979); Hawaiian (open squares), Samoan, Cook, and Austral islands, and Leg 54 and 91 basalts, from A. D. Saunders (unpublished data). Curve indicates binary mixing line between component $\mathrm{A}$ $(10 \mathrm{ppm} \mathrm{Ta}, \mathrm{La} / \mathrm{Ta}=9)$ and component $\mathrm{B}(0.03 \mathrm{ppm} \mathrm{Ta}, \mathrm{La} / \mathrm{Ta}=33)$; numbers indicate fraction of $\mathrm{A}$ in B. 